\title{
Ostracoda from the Miocene Marada Formation of Libya
}

\author{
AMAR GAMMUDI \\ Petroleum Research Centre \\ Tripoli \\ Libya
}

\author{
MICHAEL C. KEEN \\ Department of Geology \& Applied Geology \\ University of Glasgow \\ Glasgow G12 8QQ, U.K.
}

\begin{abstract}
The ostracods of the Miocene Marada Formation from three wells in the east of the Sirt Basin are described. These indicate ages ranging from Aquitainian to Tortonian. Four biozones are recognised: Pokornyella deformis minor (=Aquitainian), Aurilla soummamensis (=Burdigalian), an interval zone of Mid Miocene age, and Ruggieria tetraptera tetraptera (=Tortonian). 55 species have been identified, 22 of which are known from other Mediterranean localities. Six new species are described: Actinocythereis sirtensis sp. nov, Bythocypris tripoliensis sp. nov, Cyprideis maradaensis sp. nov, Cytheridea joshensis sp. nov, Gammudi, Hermanites zaltanensis sp. nov, and Paijenborchellina keeni sp. nov, Gammudi.

J. Micropalaeontol., 12 (1): 121-139, August 1993.
\end{abstract}

\section{INTRODUCTION}

The Sirt Basin is one of several sedimentary basins developed on the East Saharan Craton (Fig.1). Subsidence began in the Cretaceous, continued through the Tertiary, with the accumulation of more than $6000 \mathrm{~m}$ of sediment. Miocene sediments are only present in Libya in the northern Sirt Basin, adjacent areas of the Cyrenaica Platform, and a small area around $\mathrm{Al}$ khums which is $120 \mathrm{~km}$ east of Tripoli. During the Early-Mid Miocene a shallow marine gulf, fringed by lagoons and bordered by a coastal plain existed over the northern Sirt Basin (Fig 1) . The deposits of the Cyrenaica Platform are shallow marine carbonates, while the thicker sediments of the Sirt Basin include shales as well as clastics and carbonates. The Miocene of the Cyrenaica Platform is entirely Middle Miocene in age (Desio, 1928). while that of Al Khums (Al khums Formation) has recently been dated on the basis of foraminifera (Innocenti \& Pertusati, 1984) and ostracods (Al Waer, 1988, 1992) as Late Miocene, although they were previously believed to be Mid Miocene. The Marada Formation is traditionally regarded as being Early-Mid Miocene in age. The Miocene is usually unconformable with the underlying rocks, except in the south central Sirt Basin where it is conformable with the Oligoccne Diba Formation.

The wells studied here were drilled by the Wintershall Company in the eastern Sirt Basin on onshore concession 97 (Fig. 1.), and penetrate some $1200 \mathrm{ft}$. of sediment referred to the Marada Formation. The samples are ditch cuttings, each representing 30-60ft of well drilling. While it is impossible to determine the true distribution of microfossils in the wells, the first appearance downhole can be ascertained, and features such as numerical abundance and nature of preservation give some clues as to the probability of in situ occurrence. The ostracod fauna recovered from these samples is a typically diverse infralittoral fauna, with many species in common with the Miocene of the Mediterranean

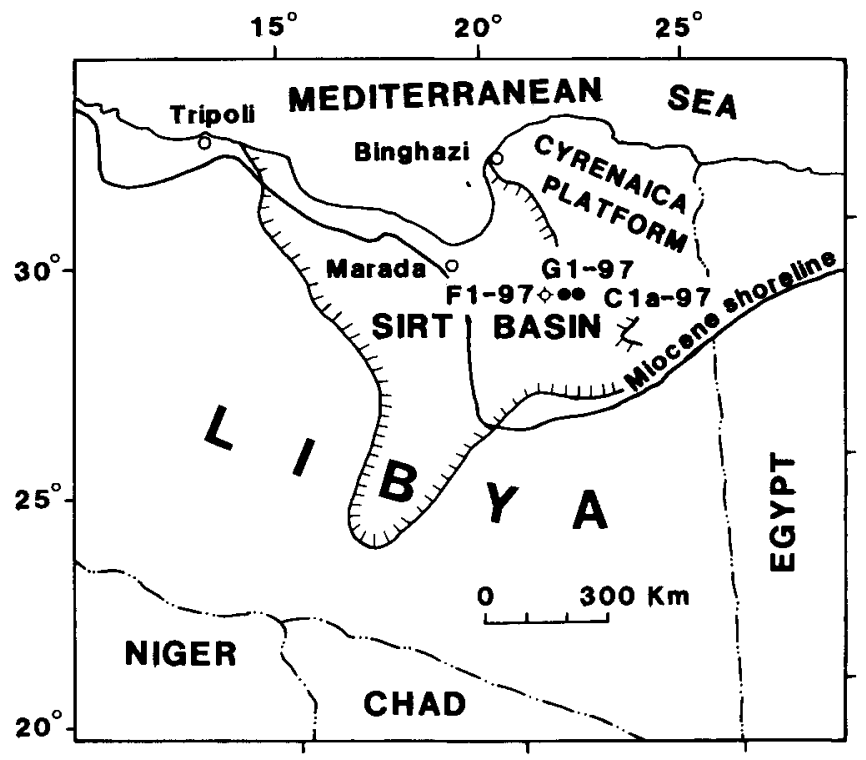

Fig.1.Map showing the Sirt Basin, the Miocene shoreline, and the position of the wells.

area in general.

\section{THE MARADA FORMATION}

Desio introduced the name Marada Series for the succession of Dor Marada, some $50 \mathrm{~km}$ northwest of Jabal Zaltan (Fig.1). The type section consists of $80 \mathrm{~m}$ of shale interbedded with sand and limestone, with some gypsum layers. It contains a marine fauna which Desio considered indicated a Langhian(Burdigalian) - Helvetian age, ie. Early to mid Miocene. Mammalian studies (Aramborg \& Magnier, 1961; Magnier, 1964; Savage \& White, 1965; and Savage \& Hamilton, 1973) suggest Early Miocene, including 
Burdigalian, for the formation at Jabal Zaltan. Hughes (1974 unpublished internal report B. G. S. No PDL $74 / 5$, in Benfield and Wright 1980) studied core samples taken from about $60-70 \mathrm{ft}$ below the top of the Marada Formation in Borehole J(C1-95) ( Lat, $27^{\circ} 27^{\prime \prime}$, Long, $20^{\circ} 43^{\prime \prime}$ ), located $85 \mathrm{~km}$ North West of well F1-97 studied here. On the basis of foraminiferal species such as Borelis melo (Fichtel \& Moll) he suggested a Middle Miocene age for this part of the Marada Formation. Innocenti \& Pertusati (1984) studied the Marada Formation of the area immediately to the north of the type area, using both macro and microfossils, including ostracods, and recognised two foraminiferal assemblages. The first of these indicates an Early Miocene age, with Miogypsina gunteri Cole, Miogypsinoide bantamensis Drooger, Archias aduncus (Fichtel \& Moll), Miogypsinoides aff dehaarti Van Den Fleak, Miogypsinoides cf complanatus Schlumberger, Miogypsina sp, and Miogypsinoides sp. An Early Miocene age is also supported by the occurrence of rare Operculina, Heterostegina, and Lepidocyclina, genera which range across the Oligocene-Miocene boundary. The second Assemblage contains Borelis melo, the first appearance of which is considered to be a good indicator for the base of the Middle Miocene, although the species ranges from the Middle Miocene to the Messinian. Thus the second assemblages was taken to indicate Middle Miocene.

Selley (1969) and El-Hawat (1980) studied the sedimentary facies of the Marada Formation in its type area, recognising fluviatile, estuarine channels, tidal inlets and flats, lagoons, barrier bar and beaches, marine banks, and marine delta fans. The succession in the type area has a thickness of $80-150 \mathrm{~m}$; it increases in thickness northwards into the centre of the basin, with a maximum recorded thickness of $2800 \mathrm{ft}$ (853m) (Wright \& Benfield 1980).

The wells studied here were drilled to the east of the type area, in a regiom which was a trough during the Miocene where some $365 \mathrm{~m}(1200 \mathrm{ft})$ of sediment accumulated. The sediments penetrated by the wells differ from those of the type area; most of the succession consists of fossilifeous limestones (marly calcarenites, some calcilutites) with common shale horizons. It is not easy to correlate these sediments with the facies described by Selley (1969) and El-Hawat (1980). The fauna (see below) indicates the predominance of shallow marine conditions, probably infralittoral, throughout the succession. Brackish water ostracods such as Cyprideis and Neocyprideis occur commonly in the lower part of the Marada Formation in the wells studied, but there is no correlation between their abundance and type of sediment. Therefore they cannot be regarded as representative of the lagoonal shale facies of Selley and El-Hawat. Lagonal facies however were clearly present in the vicinity of the wells. There is no evidence of barrier bar, beach, tidal flat, estuarine channels or fluviatile facies, because the area was presumably seaward of these facies.

\section{PREVIOUS STUDIES OF THE MIOCENE OSTRACODS OF LIBYA}

While the Miocene ostracods of the Mediterranean area have been widely studied during the past 100 years, only four studies have been published on the Miocene ostracods of Libya. The first was by Van Hinte et al (1980) who recorded ostracod faunas from the side wall core of the offshore well B1-NC35A, located about $140 \mathrm{~km}$ north east of Tripoli on the Pelagian platform. The lithology of the core shows intercalation of anhydrite between marl beds. The marls above the anhydrite were considered to be Pliocene in age, and marls below the anhydrite Miocene. The evaporites are probably evidence of the Messinian event in the area. 41 species of ostracods were recorded, including 23 named species. 11 species were only present above the evaporites, and of 30 species recorded from the Miocene only Acanthocythereis hystrix, Chrysocythere cataphracta and Neomonoceratina laskarevi have been found in this study. The reason for this great difference in faunas is partly due to stratigraphy as the faunas of Van Hinte et al are mostly younger than those of the Marada Formation, and partly due to facies where the samples of Van Hinte et al indicate predominantly circalittoral-upper bathyal $(75-500 \mathrm{~m})$ conditions.

El-Waer $(1988,1992)$ described the ostracod fauna of the late Miocene Al Khums Formation, recording 39 species including eight new species. The following species are in common between the Al Khums and Marada Formation: Actinocythereis spinosa, Actinocythereis libyaensis, Carinovalva carinata, Chrysocythere alkhumia, Cistacythereis gabilatashur-fahensis, Cnestocythere truncata, Keijella africana, Neomonoceratina mouliana, Ruggieria tetaptera tetraptera, The difference between the faunas can be accounted for by the difference in age.

Szczechura \& Abd-Elshafy (1989) studied the ostracods and foraminifera from the ?middle Miocene of the western

\section{Explanation of Plate 1}

In the following descriptions, $\mathrm{L}=$ left, $\mathrm{R}=$ right, $\mathrm{F}=$ female, $\mathrm{M}=$ male, $\mathrm{C}=$ carapace, $\mathrm{V}=$ valve. Catalogue numbers refer to the collections of the Hunterian Museum, University of Glasgow; measurements are in $\mu \mathrm{m}$.

Fig.1. Bairdoppilata triangulata Edwards: A12718, x70, L 728. Fig.2. Bairdoppilata sp.A: A12716, x55, L909. Fig. 3. Bairdoppilata sp.B: A12717, x80, L650. Figs4-6. Bythocypris tripoliensis sp. nov.: Fig.4, F L C, 12672 x63, L 816; Fig.5, F R C, A86912671, Holotype x58, L; Fig.6 M R C, 12670, x63, L800. Fig.7,: Paracypris aff. polita Sars:R C A12683, x 49, L 979. Fig.8. Paracypris sp.A: L C, A12677, x65,L 784.

Fig.9. Paracypris sp.: L C, A12680, x 80, L 644. Fig10. Dispontocypris schwejeri Van Den Bold: L C A12675, x53, L 934. Fig.11.Proponocypris sp.: R C, A12681, x 58, L 869 . Fig.12. Krithe papillosa (Bosquet): F R C, A12621, x 85, L 588. Figs 13, 14. Cnestocythere truncata (Reuss): Fig.13, F L C, A12592, x 103, L 473; Fig.14, F R C, A12593, x95, L 524. Fig.15.Cytheretta sp. A: M L C, A12666, x 60, L 833. Figs 16, 17, Cytheretta cf semipunctata(Bornemann): Fig.16, F R C, A12669, x61, L 810; Fig. 17, F L C, A 12668, x60, L 816. Fig.18. Loxoconcha gr. ovulata (Costa): F R C, A12651, x90, L 544. Fig.19. Carinovalva carinata (Moyes): M L C, A12598, x80, L637. Fig.20. Keijella punctigibba (Capeder): F L C, A12616, x78, L 632. Fig.21. Keijella africana El-Waer: F L C, A12613, x68, L 725 


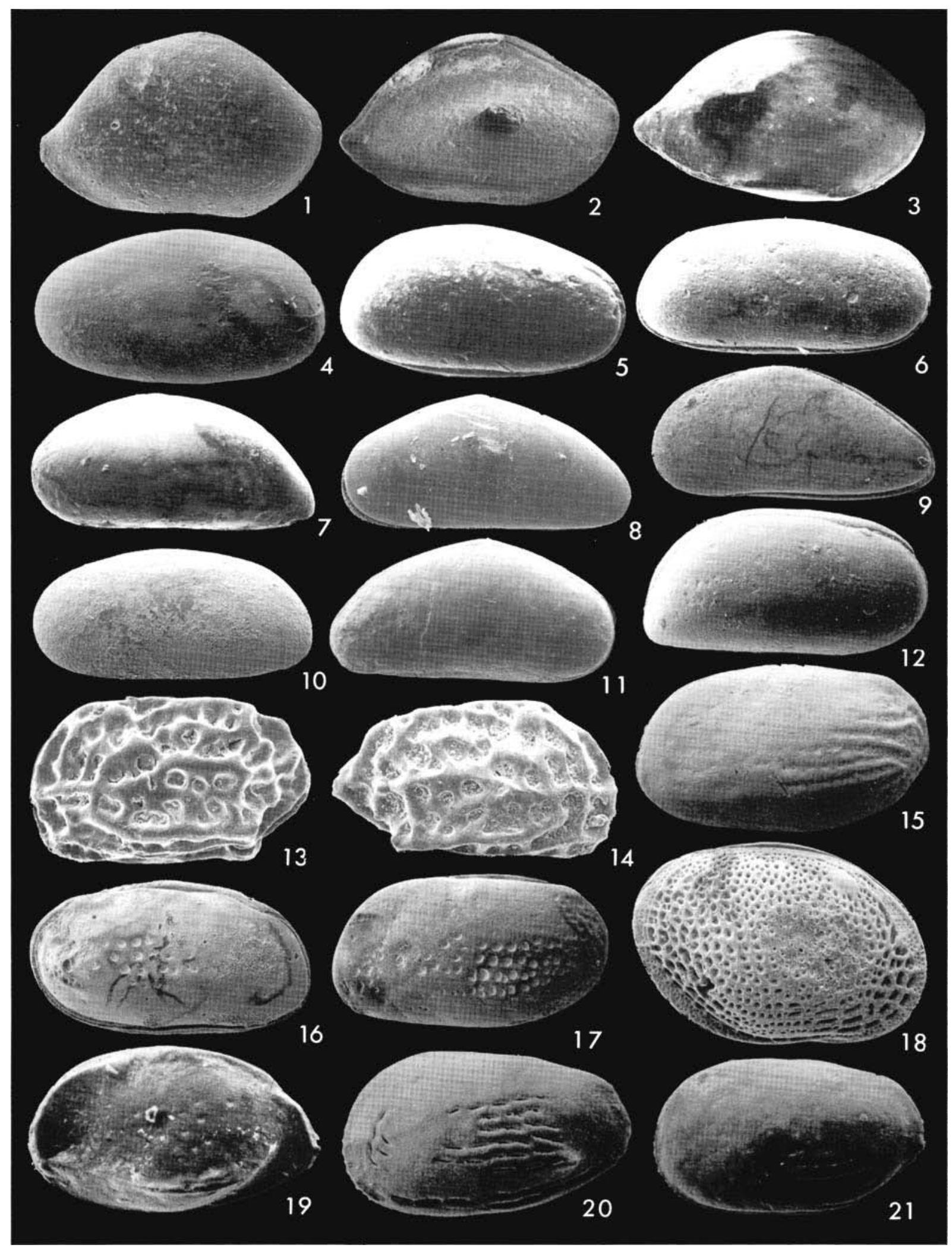


coast of the Gulf of Suez, Egypt, and from the Marada Formation of the central Sirt Basin. They recorded 55 species of ostracods from the Hommath Formation, although only 14 species are positively identified to specific level and include four new species described by Szczechura: Cytherelloidea sissinghi, Neomonoceratina keiji, Neomonoceratina ruggierii, and Hemicyprideis aegyptiaca. All of these new species were also recorded from the Marada Formation. In this study only Neomonoceratina keiji has definitely been found, together with another 11 species recorded by Szczechura \& Abd-Elshafy. Szczechura \& AbdElshafy state that about $70 \%$ of Egyptian species are present in the Marada Formation of Libya. This is not found to be the case with the species recorded in this study where there is a considerable difference. The species in common between Egypt and Libya are: Chrysocythere cataphracta, Cistacythereis of caelatura, Cnestocythere truncata, Cytherella sp. B, ?Cytheridea, Falsocythere maccagnoi, Hermanites haidingeri, Keijella africana, Neomnoceratina keiji, Neomonoceratina ruggierii, Pokornyella deformis minor, Ruggieria tetraptera tetraptera.. The fauna described from the Hommath Formation suggests the presence of Lower Miocene sediments.

No other systematic works have been published, although several faunal lists have been recorded. In a study of the middle Miocene Al-Jhaghbub Formation of eastern Cyrenaica, Bellini (1969) listed the following species identified by Ascoli: Neomonoceratina aff. N. helvetica Oertli, Miocyprideis sp, Cytherella sp, Ruggieria aff. Ruggieria tetraptera tetraptera Seguenza, Loxoconcha aff. L. punctatella Reuss, Aurila sp, Chrysocythere aff. C. cataphracta Ruggieri, Hermanites sp, Krithe sp, Cytheretta aff. C. jurinei Muenster, Quadracythere sp, Loxoconcha sp, Aurila ? aff. A. deformis Reuss, Cuneocythere? sp, Quadracythere sp, Trachyleberis? sp, Paijenborchella ? sp. The identifications are not accurate enough to allow any comparison with the ostracods of the Marada Formation.

Innocenti \& Pertusati (1984) recorded 19 ostracod species from the Marada Formation: Aurila cicatricosa (Reuss), Aurila diecii (Sissingh), Aurila impressa (Ruggieri), Aurila longa Ruggeiri, Aurila Punctata (Von Munster), Aurila trigonella (Reuss), Bairdia subdeltoidea (Von Munster), Bairdoppillata octopunctata Ruggieri, Chrysocythere cataphracta (Ruggieri), Cletocythereis minor (Ruggieri) Cnestocythere truncata ( Reuss), Cytheridea acuminata Bosquet, Kangarina coarctata Ruggieri, Loxoconcha punctatella (Ruggieri), Loxoconcha variesculpata (Ruggieri) Neomonoceratina mediterranea (Ruggieri), Neomonoceratina mouliana (Sissingh), Ruggieria tetraptera tetraptera (Seguenza), Tenedocythere mediterranea (Ruggieri). This list of species is so different from that recorded in this study that, because they are not illustrated, it is impossible to make any valid comparisons.

\section{SYSTEMATIC DESCRIPTIONS}

The material described here is stored in the collections of the Hunterian Museum, University of Glasgow, and the numbers refer to its catalogue.

Subclass Ostracoda Latreille, 1806.

Order Podocopida Müller, 1894.

Suborder Platycopa Sars 1866.

Family Cytherellidae Sars, 1866.

Three species of Cytherella Jones 1849 have been recognised (Fig.2). Cytherella cf. pulchella Ruggieri 1967 differs from the type material from the Upper Tortonian of Italy in the arrangement of the pits and in lacking a truncated posterior in dorsal view; it is more similar to C. pulchella described by Aruta (1982) from the Middle-Upper Miocene of Sicily, differing in its smaller size and less truncated posteroventral margin. Six specimens were recovered; five of these are punctate, the sixth is smooth, and is interpreted as polymorphism (See Keen 1982). Cytherella sp. A. has much coarser pitting; it is identicle to Cytherella sp. cf. Cytherella vandenboldi Sissingh 1972 of El Waer 1992 ( p.1460, pl.1 fig.1) from the Upper Miocene of Libya; it differs from $C$. vandenboldi in lacking a truncate posterior margin in dorsal view. Cytherella sp. B has been described and illustrated by Szczechura and Abd-Elshafy as Cytherella sp. (1989,p. 290, pl. 2a-b,7?). One specimen of the genus Cytherelloidea Alexander, 1929 has been found, illustrated as Cytherelloidea sp.

Material. C. cf. pulchella, 3 carapaces and 3 valves; No A12653-655 from Well F1-97 at depth 1590-1740ft; C.sp.A, 2 carapaces; No A12646,7 from Well C1a-97 at depth of 770ft. C.sp.B, 4 carapaces; No A12644,5 from Wells C1a-97 at depth $770 \mathrm{ft}$ and F1-97 at depth 1530ft. Cytherelloidea sp., 1 carapace, No A12652 from Well G1-97 at depth 1230 feet.

\section{Suborder Podocopina Sars, 1866 \\ Superfamily Bairdiacea Sars, 1888 \\ Family Bairdiidae Sars, 1888}

Genus Bairdoppilata Coryell, Sample \& Jennings, 1935 Three species of this genus have been recognised. Bairdoppilata triangulata Edwards, 1944 is conspecific with the species described under this name by Keij (1955) and

\section{Explanation of Plate 2}

Figs1,4 stereoscopic paired photographs, internal views.

Figs 1-3, 7. Cyprideis maradaensis sp. nov.: Fig.1, F L V, Holotype, A12581, x75, L 670; Fig.2, F R C, A12582, x73, L 735; Fig.3, M R C, A12583, x79, L 639; Fig.7, F V C, A12585, x78, L 651. Figs 4,8, 11, 16. ?Cytheridea sp. : Fig.4, F L V, A12708, x88, L 558; Fig.8,F D C, A12710, x90, L 566; Fig.11, M L C, A12709, x83, L 624; Fig.16, M R C, A12707, x83, L 618. Fig.5. Cyprideis sp.A: R C, A12586, x78, L 658.

Fig.6.Neocyprideis sp.: L C, A12591, x68, L 755. Figs 9,10, 12, 14. Cytheridea joshensis sp. nov. Fig.9, F R C, Holotype, A12711, x90, L 566; Fig.10, M R C, 12713, x83, L 612; Fig.12, F D C, 12714, x98, L 525; Fig. 14, M L V, 12712, x88, L 588. Fig.13.Hermanites zaltensis sp. nov.: F D C, A12701, x64, L 781. Fig.15. Cytheridea sp. R C, A12715, x90, L 520. Fig.17. Cyprideis sp. B: R C, A12589, x73, L 668. Fig.18. Neocaudites nudicosta (Yassini): R C, A12687, x80, L 637 . 


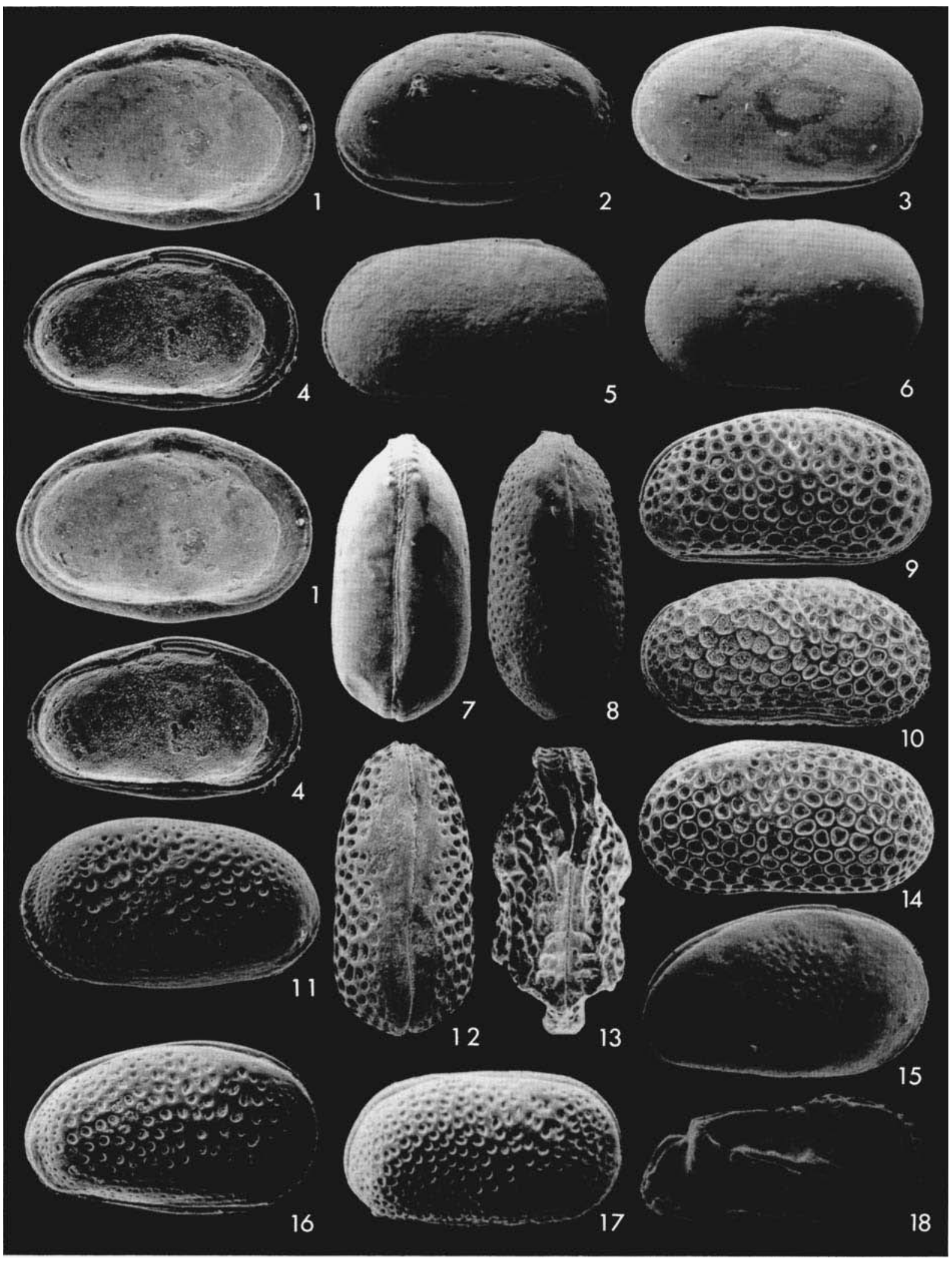




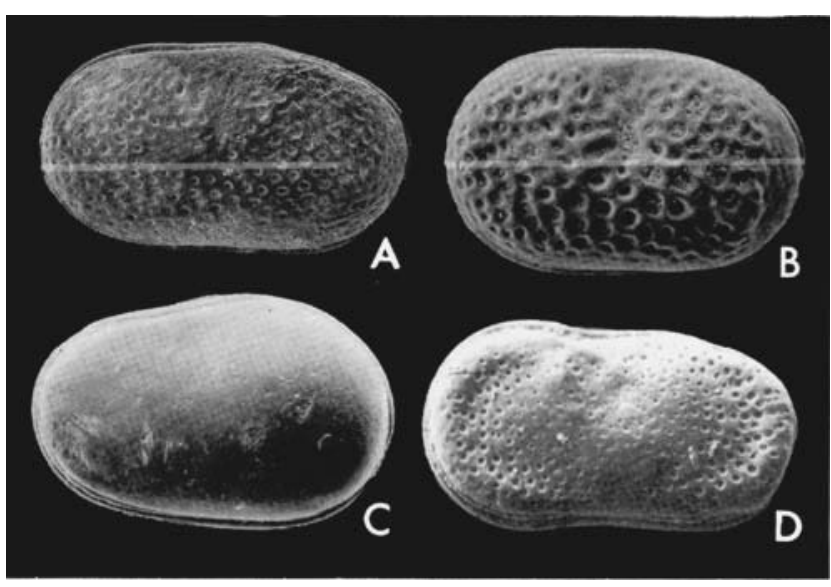

Fig.2. A. Cytherella of porchella Ruggieri, female left car, A12654, x64, L 625; B .Cytherella sp. A, left car, A12646, x77, L 519; C. Cytherella sp. B, left car, A12644, x60, L 673; D. Cytherelloidea sp., left car, A12652, x85, L 600 .

Moyes (1965) from the Aquitanian of southwest France, but it is not clear whether these should really be placed into Edwards' species which was described from the Miocene of North Carolina, U.S.A. Bairdoppilata sp. B and differs from Bairdoppilata sp.A in its smaller size and in having a more evenly curved dorsal margin, more pointed posterior, and a less upwardly curved postero-ventral area.

Genus Bythocypris Brady, 1880

Material. B. triangulata, 2 valves; No A12718, from Well C1a-97 at depth 1730 feet; B.sp.A 2 carapaces, No A12716 from Wells G1-97 at depth 1260ft and F1-97 at $1530 \mathrm{ft}$; B.sp.B, 2 carapaces; No A1271 from Wells G1-97 at depth $1540 \mathrm{ft}$ and F1-97 at $1110 \mathrm{ft}$.

\section{Bythocypris tripoliensis sp. nov}

(Pl.1, figs 4-6)

Derivation of name. After the capital of Libya.

Diagnosis. Carapace elongate in lateral outline; dorsal margin arched; surface smooth.

Holotype. Female right carapace; No A12671, from well G197 at depth of $1540 \mathrm{ft}$.

Material. Twenty five carapaces and one valve, occurring throughout all three wells; No A12670-673.

Description. Carapace elongate in lateral view, with greatest height near centre of carapace. Left valve larger than right, overlapping all around margin; dorsal margin arched; ventral margin slightly convex in left valve. relatively straight in right; anterior margin broadly rounded; posterior margin obliquely rounded; carapace ovoid in dorsal view; maximum length centrally. The surface of the carapace is smooth. Internal features not observed. Sexual dimorphisim is distinct with smaller and more elongate males.

Dimensions of figured specimens (in $\mu \mathrm{m}$ ).

$\begin{array}{lccc} & \text { Length } & \text { Height } & \text { L/HH } \\ \text { Female right carapace; No A12671 } & 869 & 459 & 1.85 \\ \text { Female left carapace; No A12672 } & 816 & 432 & 1.88 \\ \text { Male right carapace; No A12670 } & 800 & 368 & 2.17\end{array}$

Remarks. This shows some similarty to the specimens described as Bythocypris alejo Reyment by Carbonnel (1986), although the outline is not quite the same, the species described here being more elongate. It is also similar in size to Disopontocypris schwejeri Van Den Bold (1966), but differs from the latter in the outline of the dorsal and anterior margins; in $B$. tripoliensis the dorsal margin slopes downwards towards the anterior giving a more tapered anterior in the female, and has a more humped dorsal margin.

\section{Superfamily Cypridacea Baird, 1845 \\ Family Cyprididae Baird, 1845}

Subfamily Disopontocypridinae Mandelstam, 1956

Genus Disopontocypris Mandelstam, 1956

Disopontocypris schwejeri Van Den Bold, 1966

(Pl. 1, fig. 10)

Material. 9 carapaces and 1 valve; only present in Well C1a97 between 770-950 ft.; No A12674-76.

Remarks. This was originally described from the Neogene of Gabon (Van Den Bold 1966), and subsequently from the Burdigalian of Algeria (Coutelle \& Yassini, 1974) and the Neogene of Senegal (Carbonnel 1986). The specimens described here are larger than those listed above:

$\begin{array}{lcc} & \text { Length } & \text { Height } \\ \text { Right carapace; No A12674 } & 984 & 468 \\ \text { Left carapace; No A12675 } & 934 & 436 \\ \text { Coutelle \& Yassini(1974) } & 620 & 430 \\ \text { Van Den Bold (1966) } & 790 & 370 \\ \text { Carbonnel(1986) } & 850 & 420\end{array}$

There seems to be an error in the dimensions given by Coutelle \& Yassini according to their photographs. The Libyan specimens are very similar in outline to those illustrated by Carbonnel.

\section{Explanation of Plate 3}

Figs 1-3. Aurila soummamensis Coutelle \& Yassini: Fig.!, M L C, A12559, x71, L 711; Fig.2, F R C, A12562, x78, L 685; Fig.3, M R C, A12558, x 74, L 693. Figs 4,5. Aurila gr. convexa: Fig.4, F L C, A12566, x 100, L510; Fig.5, M L C, A12569, x90, L 556.

Fig.6. Urocythereis cf. sorocula (Seguenza): L C, A12706, x93, L541. Figs 7-9. Pokornyella deformis minor (Moyes): Fig.7, M R C, A12624, x73;, L 689 Fig.8, F R C, A12625, x68, L 725; Fig.9, F L C, A12626, x70, L 714. Figs 10, 12. Pokornyella sp.: Fig.10, F R C, A12630, x 75, L653; Fig.12, M L C, A12631, x 75 L 680. Fig.11.Pokornyella cf. deformis: F R C, A12632a, x 67, L 748. Fig.13 Neomonoceratina keiji Szczechura: F R C, A12608, x103, L 468. Figs 14, 17. Paijenborchellina libyca Szczechura: Fig.14, F R C (posterior broken), A12688, x85, L 588; Fig.17, F L V, A12689, x73, L 703. Fig.15. Neomonoceratina laskerevi Krstic \& Pietrzeniuk: M R C, A12602, x90, L 561. Figs 16,19, 20. Paijenborchellina keeni Gammudi sp. nov.: Fig.16, M R C, Holotype, A12691, x 78, L 850; Fig. 19, M R C, A12692, x76, L 666; Fig. 20, F R C, A12690, x78, L 638. Figs 18, 21. Falsocythere maccagnoi Ciampo: Fig. 18, M L C, A12685, x85;, L 600; Fig.21, F R C, A12684, x90, L 538 


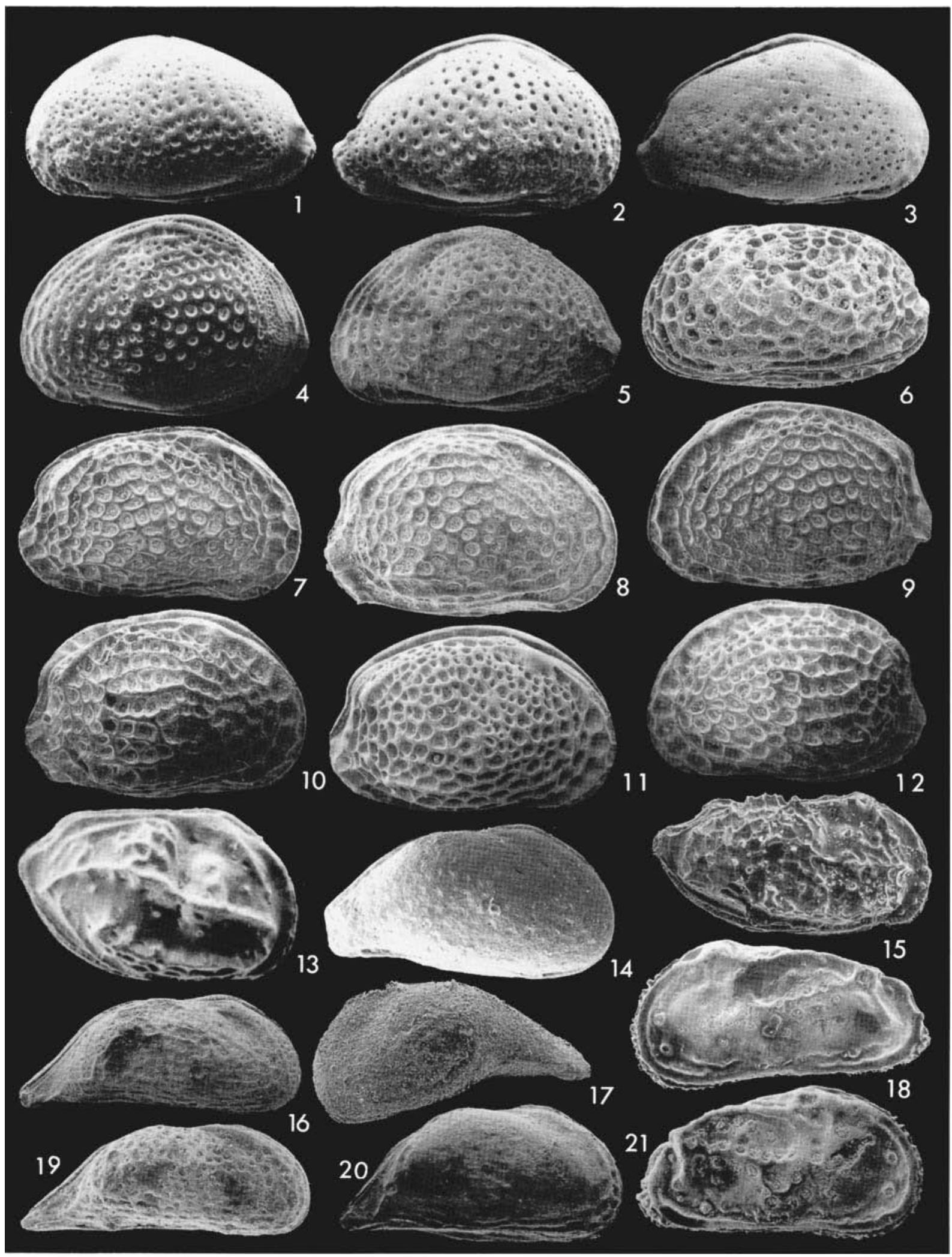


Family Paracyprididae Sars, 1923

Genus Paracypris Sars, 1866

Three species of this genus have been recognised. Paracypris aff $P$. polita Sars 1866 resembles Paracypris polita Sars (1866) described from the Burdigalian of South West Anatolia, Turkey, by Gokçen (1986); the latter differs in lateral outline, being more elongate and having a more tapered posterior margin and more obliquely rounded anterior margin. Paracypris polita described from the Upper OligoceneHelvetian of the Aquitaine Basin (Keij, 1955 and Moyes 1965), differs in being more elongate and in having a highly tapered posterior. Paracypris sp. A shows similarities with Paracypris rosefieldensis described from the lower Miocene of Southern Trinidad (Van Den Bold, 1957) but the latter has a more pointed posterior and it is larger. $P$. sp. A differs from Propontocypris sp. in the pointed posterior margin and smaller size. Paracypris sp. shows some similarities to Paracypris $s p$ described from the Neogene of Rhodes (Mostafawi, 1989), but the latter differs in having maximum height at $1 / 3$ length of carapace from anterior, dorsal margin is slightly rounded, and postero-dorsal margin slightly curved rather than straight. This species also shows some similarities with Paracypris polita Sars described from the Burdigalian of south west Anatolia, Turkey (Gokçen1986), but differs in having a longer and curved antero-dorsal margin.

Material. P. aff.P.polita, 1 carapace; No A12683 from Well C1a-97 at depth 1730 feet. ; P. sp.A, 5 carapaces, No A1267779 from Well F1-9 at 990 , $1170 \mathrm{ft}$.; P.sp.,1 carapace, No A12680 from Well F1-97 at depth $1290 \mathrm{ft}$.

Family Pontocyprididae G. W. Müller, 1894

Genus Propontocypris Sylvester-Bradley , 1947 Propontocypris sp.

(Pl.1, fig. 11)

Material. 2 carapaces; No A12681-682 from Well C1a-97 at depth of $1340 \mathrm{ft}$.

Superfamily Cytheracea Baird,1850

Family Cytheridae Baird, 1850

Genus Cnestocythere Triebel, 1950

Cnestocythere truncata (Reuss, 1850)

(Pl. 1, figs. 13, 14)

Material. 2 carapace and 1 valve; No A12592-3; Well Gi97,1570ft.; WellF1-97, 1050,1230.

Remarks. This widespread species, first described from the
Tortonian of the Vienna Basin (Reuss 1850) is also recorded from the Aquitanian-Burdigalian of France (Keij 1955, Moyes 1965, and Carbonnel 1969) from the Tortonian of central Sicily (Ruggieri 1962), from the Upper Miocene of Libya (El-Waer,1992) and from the ?middle Miocene Marada Formation and Hommath Formation of Egypt (Szczechura. \& Abd-Elshafy 1989). Triebel (1950) described two species from the Tortonian of the Vienna Basin: Cnestocythere lamellicosta n.sp. and C. truncata (Reuss); the former has sharp and high ridges while the latter has low rounded ridges, our specimens have low and rounded ridges.

Family Cytherettidae Triebel, 1952

Genus Cytheretta G. W. Müller, 1894

Two species are recorded, Cytheretta cf. semipunctata Bornemann, 1885 and Cytheretta sp. A. The former is similar to Cytheretta aff semipunctata described from the Lower Miocene of the Rhone Basin in France (Carbonnel 1969), but differs in shape and arrangement of punctae. In our specimens these are variable in size, forming four rows in the postero-central area and extending both posteriorly and anteriorly as scattered and smaller sized punctae; the remainder of the carapace is smooth.

Cytheretta sp. $A$ has an ornamentation consisting of seven longitudinal ridges in the posterior part of the carapace, with weakly developed reticulation between them; one specimen also has very indistinct rows of punctae in the antero-ventral part of the valve. It is similar to Cytheretta ishizakii Bonaduce at al 1992, described from the Sahelian of offshore Tunisia. It differs in lacking the postero-ventral punctae which characterise C. ishizakii. El Waer (1992) described two species, Cytheretta sp. A and Cytheretta sp.B from the late Miocene of Libya.They appear to us to be conspecific, the only difference being the greater prominence of the punctae in Cytheretta sp.A. Our species lacks the punctae present in the postero-dorsal, central, and ventral areas of El Waers's species. The presence of these punctae also separates El Waer's species from C. ishizakii. These three taxa do appear to be closely related however. Material. Cytheretta cf. semipunctata, 3 carapaces; No A12667-669 from Well F1-97 at $1230 \mathrm{ft}$. Cytheretta sp. A 6 carapaces; No12663-666 from Well C1a-97 at depth of 770 feet.

Family Cytherideidae Sars, 1925

Explanation of Plate 4

Figs1,4 stereoscopic paired photographs.

Figs 1-3. Actinocythereis sirtensis sp. nov.: Fig.1, F R C, Holotype, A12556, x80, L 638; Fig.2, M R C, A12554, x74, L 700; Fig.3, M L C, A12555, x76, L 672. Figs 4, 9, 11. Hermanites zaltanensis sp. nov.: Fig.4, F R C, A12699, x60; L 841 Fig.9, F L C, A12700, x60, L 875; Fig.11, M R C, Holotype, A12698, x53, L 952. Fig.5. Actinocythereis libyaensis El-Waer: F R C, A12553, x70, L 714. Fig.6. Hermanites haidingeri haidingeri (Reuss): F R C, A12704, x70, L 714. Fig.7. Actinocythereis spinosa El-Waer: L V, A12550, x60, L 815. Fig.8. Acanthocythereis hystrix (Reuss): F L C, A12634, x70, L 742. Fig.10. Ruggieria aff. dorukae Bassiouni: M R V, A12641, x73, L 669. Fig.12. Cistacythereis qabilatshurfahensis El-Waer: R C, A12594, x90, L 566. Fig.13. Cistacythereis cf. caelatura Uliczny: F L V, A12659, x80, L 637. Fig.14. Ruggieria tetraptera tetraptera Sequenza: M R C, A12638, x60, L 833. Fig.15. Caudites sp.: R C, x64, L 765. (specimen lost) Fig.16.Xestoleberis cf. reymenti Ruggieri: F L C, A12696, x95, L 515. Fig.17. Chrysocythere cataphracta cataphracta Ruggieri: F R C, A12573, x70, L716. Fig.18. Chrysocythere alkhumia E1-Waer: F R V, A12571, x83, L 599. Fig.19. Chrysocythere paradisus Doruk: F R C, A12579, x68, L 772. 


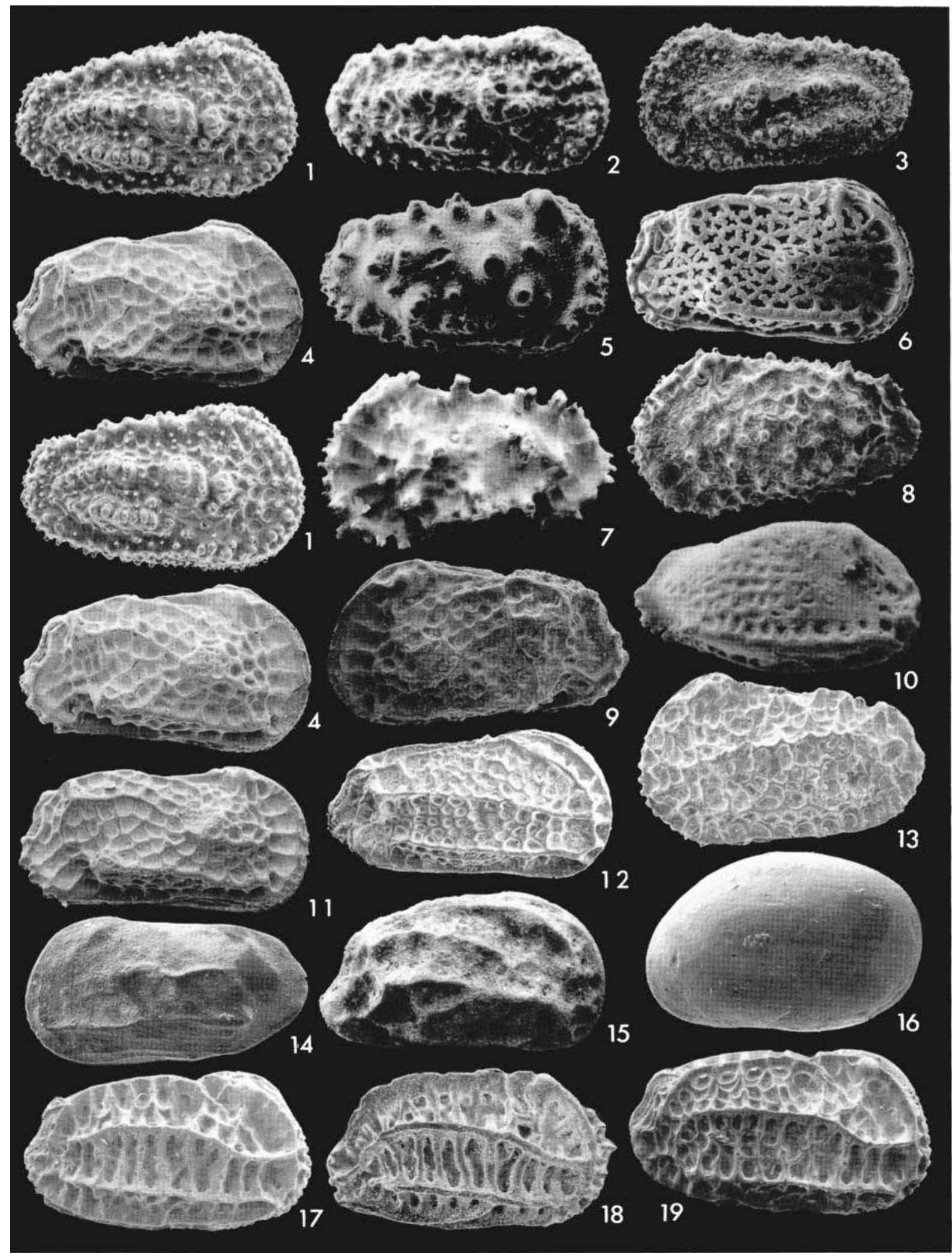




\section{Subfamily Cytherideinae Sars, 1925 \\ Genus Cytheridea Bosquet, 1852 \\ Cytheridea joshensis sp. nov Gammudi}

(Pl.2, figs 9, 10, 12, 14.)

Derivation of name. After Josh village, Libya.

Diagnosis. A species of Cytheridea with surface ornamented by large deep rounded pits.

Holotype. Female right carapace; No A12711; well C1a-97 at depth $770 \mathrm{ft}$.

Material. Twenty carapaces; No A12711-714. Present in all three well

Description. Carapace subovoid in lateral view; with greatest height near anterior; anterior margin evenly rounded, some specimens have very fine spines in the antero-ventral area; posterior margin obliquely rounded; dorsal margin slightly convex and gently sloping posteriorly; ventral margin straight in left valve while in right valve it is slightly concave centrally; maximum height at dorsal cardinal angle. Surface of carapace ornamented by large deep rounded pits; the area of the muscle scars has fossae arranged in a group like the petals of flowers. In dorsal view carapace has almost parallel sides, with bluntly rounded anterior, and posterior margins widest near posterior. Internal features not known. Sexual dimorphisim is pronounced, males being more elongate than females.

Dimensions of figured specimens (in $\mu \mathrm{m}$ ).

Length Height $\mathrm{L} / \mathrm{H}$

$\begin{array}{llll}\text { Female right carapace; No A12711 } & 566 & 305 & 1.85\end{array}$

$\begin{array}{llll}\text { Male right carapace; No A12713 } & 612 & 315 & 1.94\end{array}$

$\begin{array}{llll}\text { Male left valve; No A12712 } & 588 & 308 & 1.92\end{array}$

Remarks. This shows slight similarities to Cytheridea fourniei described by Carbonnel (1969) from the Lower Miocene of the Rhone Basin, especially with the surface ornamentation, anterior and ventral margins. The lateral outline differs from typical Cytheridea in being less tapered towards the posterior and with a posterior cardinal angle which is quite angular.

\section{Cytheridea sp.}

(P1.2, fig.15.)

Material. Five carapaces; No A12715. from Wells C1a-97 at depth 1220ft, G1-97 at 670, 970 and 1010ft and F1-97 at $1530 \mathrm{ft}$.

Remarks. This is similar to Cytheridea josephinae Kollmann 1960, recorded from the middle Tortonian of Austria, but differs in the postero-ventral area being broadly rounded as well as in the ornamentation which consists of different sized weak punctae situated in the centre of the valves, the remainder of the carapace being smooth.

\section{? Cytheridea sp.}

(Pl.1, figs 4,8,11,16)

1989 ?Miocyprideis of italiana Szczechura, p. 94-95, pl. 4, figs.1-11.

Material. 13 carapaces and seven valves; No A12707-710. Description- Carapace subtrapezoid to subrectangular in lateral outline; anterior margin broadly rounded; posterior margin obliquely rounded; dorsal margin straight or slightly convex with distinct cardinal angle; ventral margin sinuate, concave in posterior half and slightly convex anteriorly; left valve larger than right and strongly overlapping the whole margin except central anterior. The anterior and posterior ends are flattened; there are 9-10 anterior denticles. Surface of carapace ornamented by rounded pits, the marginal pits are very fine and arranged in rows parallel to the carapace margins. The hinge is tripartite; in the left valve there is an anterior elongate crenulate socket with a thickened ventral wall, a prominent crenulate median element which is sharply defined both to anterior and posterior and situated on a thickened part of the dorsal wall, and a posterior crenulate groove deepening posteriorly; the anterior and posterior elements are of approximately the same length, the median element slightly shorter. Muscle scars typical of the genus. Dimensions of figured specimens (in $\mu \mathrm{m}$ ).

$\begin{array}{lccr} & \text { Length } & \text { Height } & \text { L / H } \\ \text { Male right carapace; No A12707 } & 618 & 357 & 1.73 \\ \text { Female left valve; No A12708 } & 558 & 388 & 1.43 \\ \text { Male left carapace; No A12709 } & 624 & 351 & 1.77 \\ \text { Female Dorsal view; No A12710 } & 566 & - & 272\end{array}$

Remarks. The generic asignment of this species is difficult. Lateral outline suggests Cytheridea, i.e. the highest point is towards the anterior rather than the centre or posterior as in Cyprideis, Neocyprideis and Miocyprideis Kollman 1960. The hinge however is not that of typical Cytheridea, as the posterior element cannot be subdivided into two parts. The tripartite hinge resembles that of Miocyprideis and Hemicyprideis Malz \& Triebel 1970, but differs in having a short median element and in the massive nature of the anterior and median elements. The thickened ventral wall of the anterior socket is reminiscent of Vetustocytheridea Apostolescu 1956, while the overall appearance also suggests Hemicyprideis. Bonaduce et al (1992) described a new species, "Cytheridea"nasuta, from the Pliocene of offshore Tunisia which ressembles our species in shape, ornament, hinge and muscle scars, although the dorsal margin is straighter and the species is larger (c.720 $\mu \mathrm{m})$.

\section{Genus Cyprideis Jones, 1857 \\ Cyprideis maradaensis sp. nov.}

(Pl.2, figs 1-3, 7)

Derivation of name. After Marada Oasis $120 \mathrm{~km}$ south Sea shore.

Diagnosis. Massive carapace ovate to reniform and smooth with scattered seive pore canals gives the surface a punctate appearance.

Holotype. Female left valve; No A12581, well F1-97 at depth of $1320 \mathrm{ft}$.

Material. Sixteen carapaces and one valve; No A12581-585; Wells C1a-97, G1-97 and F1-97.

Description. Carapace ovate to reniform in lateral view, left valve markedly larger than the right; dorsal margin of left and right valves differ in outline, left valve is almostly straight while the right is arched; maximum height at the 
centre of the carapace; anterior margin broadly rounded with some seven small spines on both valves; posterior margin obliquely rounded; ventral margin nearly straight but slightly concave in the antero-ventral area while in the left valve weakly convex; Surface of carapace has scattered punctae; some of these are seen to be sieve type normal pore canals, others are too ill preserved to be sure whether they are pore canals. Internal feature very clear and typical of the genus. Males smaller and slightly more elongate than females.

Dimensions of figured specimens (in $\mu \mathrm{m}$ ).

$\begin{array}{lccc} & \text { Length } & \text { Height } & \text { L / H } \\ \text { Female left valve; No A12581 } & 670 & 445 & 1.50 \\ \text { Female right carapace; No A12582 } & 735 & 442 & 1.66 \\ \text { Male right carapace; No A12583 } & 639 & 379 & 1.68\end{array}$

Remarks- This differs from any described species.

\section{Cyprideis sp. A}

$$
\text { (Pl.2, figs.7) }
$$

Material. 8 carapaces; No A12586-588 from Well Cla-97 at depth 1340 feet. Remarks. This species is placed in Cyprideis on the basis of subrectangular lateral outline as no internal feature have been observed. It has some similarities with Cyprideis similis (Bradely) figured by Van Den Bold. (1963) from the Upper Miocene and Pliocene of Trinidad. The latter species differs in having a more truncated posterior end and lacks the small postero-ventral flangepresent in our species. The carapace is smooth to slightly pitted, and sexual dimorphism is not pronounced.

\section{Cyprideis sp . B.}

(Pl.1, fig.17)

Material. 3 Carapaces; No A12589 from Well G1-97, 1510$1570 \mathrm{ft}$.

Remarks. This species is very similar to Cyprideis sp. A in lateral outline; it differs in having an ornamentation of prominent pits; finer pits arranged in four rows parallel to the anterior and posterior margins, and coarse pits over the remainder of the carapace; it is also has a small posteroventral spine in the right valve. No internal features have been observed.

\section{Genus Neocypridies Apostolescu,1956 Neocyprideis sp (Pl.2, fig. 6)}

Material. 5 carapaces; No A12590-91. Wells C1a-97 at depth,1280, 1550; G1-97, 880; F1-97, $840 \mathrm{ft}$.

Remarks. This is placed in Neocypridies on the basis of lateral outline; no internal feature have been observed. It shows some similarity to Neocyprideis rara Goerlich, 1953 subspecies cerestel in Carbonnel (1969) recorded from the Upper Oligocene of France, but differs in having a more rounded postero-dorsal margin.

Subfamily Krithinae Mandelstam in Bubikan, 1958

Genus Krithe Bradely, Crosskey \& Robertson, 1874 Krithe papillosa (Bosquet ), 1852
(P1.1, fig. 12)

Material. Thirty carapaces and eight valves from throughout all wells; No. A12619-23.

Family Cytheruridae G. W. Müller, 1894
Genus Paijenborchellina Kuznetsova, 1957
Paijenborchellina libyca Szczechura, 1980

(Pl.3, figs 14, 17)

Material. 5 carapaces and 1 valve; No A12688-689 from Wells C1a-97 at depth 1400, 1610ft, G1-97 at 1470ft and F197 at $780,810 \mathrm{ft}$.

Remarks. This was described from outcrops of the Upper Miocene of the northern Sirt Basin between Marada Oasis and the Dahra oil fields (Szczechura, 1980).

\section{Paijenborchellina keeni sp. nov Gammudi}

(Pl. 3, figs 16, 19, 20)

Derivation of name. In honour of Dr. M.C. Keen.

Diagnosis. Caudal process relatively short; whole carapace reticulate; central area with weak longitudinal ribs, the ventral most of which is clearly defined at the posterior where it bends sharply downwards.

Holotype. Male right carapace; No A12691, well F1-97 at depth of $810 \mathrm{ft}$.

Material. Ten carapaces; No A12690-93; Well C1a-97, 1340ft.; G1-97, 640; F1-97, 780-810 ft.

Description. Carapace pear shaped in lateral view; anterior margin slightly obliquely rounded; dorsal margin rounded and saddle like; ventral margin straight; maximum height at antero-dorsal area one third from anterior, i.e. at maximum curvature dorsally; reticulation over entire carapace surface. One specimen (Pl.3, fig. 20) is poorly reticulate but has well developed reticulation around the anterior margin; this may be due to preservation or indicate infraspecific variation. Central area with longitudinal ribs, ventral most of which is clearly defined at posterior where it bends sharply downwards; there is a weak depression parallel to the anterior margin. Internal features not known. Sexual dimorphisim is distinct, with more elongate males.

Dimensions of figured specimens (in $\mu \mathrm{m}$ ).

$$
\text { Length Height } \mathrm{L} / \mathrm{H}
$$

Male right carapace; No A12691 $\quad 650 \quad 258 \quad 2.5$

$\begin{array}{llll}\text { Male right carapace; No A12692 } & 666 & 253 & 2.63\end{array}$

Female right carapace; No A12690 $638 \quad 316 \quad 2.00$

Remarks. Paijenborchellina keeni shows some similarities toPaijenborchellina libyca (Szczechura,1980) differing in having a relatively short caudal process, in lateral outline, as well as having differently shaped reticulation. P.punctata El-Waer 1992 differs in being finely punctate and is also more elongate.

Family Hemicytheridae Puri, 1953

Genus Aurila Pokorny, 1955

Aurila soummamensis Coutelle \& Yassini, 1974

(Pl.3, figs1-3) 
1974 Aurila soummamensis n sp Coutelle \& Yassini, 1974. p.93, pl.1, figs.10, 11, 13, 14, 17, \& pl.3, fig.11.

1979 Aurila soummamensis Coutelle \& Yassini, Bassiouni, p.123, pl. 20, figs.12-15.

1984 Aurila soummamensis Coutelle \& Yassini, Gokcen, p.4748, figs.1-5.

Diagnosis. A species of Aurila with triangular lateral outline; dorsal margin broadly arched and ornamented with fine to medium punctae.

Material. 25 carapaces and 2 valves; No A12558-56 from the lower parts of all wells;from 1070 downwards in C1a-97, 880 in G1-97, and 1020 in F1-97.

Remarks. Aurila soummamensis is recorded from the Lower Miocene of Algeria (Coutelle \& Yassini1974) and Turkey (Bassiouni, 1969, Gokcen 1984).

\section{Aurila gr convexa Baird, 1850}

(Pl.3, figs 4,5)

Material. Fifteen carapaces and four valves; No A12565-570; C1a-97, 830,1130, 1280-1340; G1-97, 1100,1230; F1-97, 1200, $1410,1500,1590-1650$.

Description. Carapace triangular in lateral view; dorsal margin rounded to arched; maximum height slightly behind centre of carapace; anterior margin obliquely rounded; posterior margin truncate with very short caudal process; ventral margin concave in the anterior part and slightly convex posteriorly; left valve larger than right valve and strongly overlaps the right; the surface is ornamented by variable sized punctae; anterior margin with four parallel rows of quadrate reticulation. No internal feature were observed. Sexual dimorphisim is distinct, males being more elongate than females.

Remarks. Aurila gr convexa is similar to Aurila (Aurila) maculosa (Uliczny 1969) in lateral outline but the latter has its maximum height located at the mid length of the carapace while in our specimens the maximum height is situated just to the posterior of mid length.

\section{Genus Caudites Coryell and Field, 1937 Caudites sp. (Pl.4, fig. 15)}

Material. One carapace lost after photography, from Well C1a-97 at1070ft.

Genus Pokornyella Oertli, 1956

Pokornyella deformis minor (Moyes, 1965)

(P1.3, figs 7-9)

1955 Hemicythere deformis Reuss, Keij, p.123, pl. 8, figs. 5-7.

1965 Hemicythere deformis minor Moyes n ssp p.99, pl.13, figs. 1-4 1977 Pokornyella deformis minor (Moyes), Ruggieri, Russo, Bossio, pl.1, figs 2-4b.

1979 Pokornyella deformis minor (Moyes), Bassiouni, p.112113. pl.19, figs. 18-21.

1986 Hemicythere deformis minor Moyes, Gokçen, p. 47, pl. 3, figs 11-21.

1989 Pokornyella deformis minor (Moyes), Szczechura \& AbdElshafy, p. 306-307, pl. 6, Fig. 1,2a ,2b.
Material. 25 carapaces and 4 valves from all wells; No A12624-629.

Remarks. Pokornyella deformis minor Moyes is smaller than the nominate subspecies. It is recorded from the lower Miocene of the Aquitain Basin in France (Moyes, 1965), the lower Miocene of Turkey (Bassiouni, 1979), the lower Aquitanian to Burdigalian of the Kale-Yensehir region of Turkey (Gokçen 1985-86) and is described from ?middle Miocene of the central Sirt Basin and western coast of the Gulf of Suez, Egypt (Szczechura \& Abd-Elshafy 1989). Ruggieri, Russo \& Bossio (1977), have illustrated topotype material of both Pokornyella deformis deformis and Pokornyella deformis minor. The diagnostic feature of $P$. deformis minor, apart from smaller size, is the presence of a short ridge at the postero-dorsal angle.

\section{Pokornyella cf $P$. deformis (Reuss) 1850.}

(Pl.3, fig. 11)

Material- Eight carapaces from Well C1a-97 at depth of 770 to $1160 \mathrm{ft}, \mathrm{G} 1-97$ at $640,910-970 \mathrm{ft}$ and F1-97 at $1120-1150$, 1200-1230ft.; No A12632.

Remarks. The specimens differ from Pokornyella deformis minor in having a more arched dorsal margin, especially at the posterior, having a stronger ventral ridge and in being coarsely punctate rather than reticulate. It has fine punctae around the dorsal and antero-dorsal margins.

\section{Pokornyella sp.}

(Pl.3, figs 10, 12)

Material- Twelve carapaces and two valves from Wells Cla97 at depth $950,1010,1280 \mathrm{ft}, \mathrm{G1}-97$ at $1160 \mathrm{ft}$ and F1-97 at 690 and 720ft; No A12630-631.

Remarks. This is similar to Procythereis sulcatopunctatus (Reuss 1850) described from the middle Miocene of Turkey by Bassiouni (1979), but differs in having a more curved dorsal margin, and a more obliquely rounded anterior margin. This is very similar to Procythereis sulcatopuntatus of El-Waer (1992)) from the Upper Miocene Al khums Formation of Libya.

\section{Genus Urocythereis Ruggieri, 1950 \\ Urocythereis cf. U. sorocula Uliczny, 1969 (Pl.3, fig.6)}

Material.One carapace from Borehole G1-97 at depth of 1190 ft; No A12706.

Remarks. This shows great similarities in lateral outline to Urocythereis sorocula from the Pliocene of Reggio di Calabria (Sissingh, 1972) but the latter differs in having elongate groove more or less parallel to the anterior margin which is weakly developed in our species, as well as differences in the pattern of reticulation. $U$. sororcula is also described from the Pliocene of Spain (Carbonnel \& Magne, 1977).

\author{
Family Loxoconchidae Sars, 1925 \\ Genus Loxoconcha Sars, 1866 \\ Loxoconcha gr ovulata (Costa), 1853
}

(Pl.1,fig. 18) 
1853 Cytherina ovulata Costa, p.177,pl.16, fig.7. 1984 Loxoconcha gr ovulata (Costa), Bonaduce \& Russo, p. 434, pl. 5, fig. 9.

Material. Eight carapaces; No A12648-651; Well C1a97,950,1130,1220, 1610; Well G1-97, 1190,1260, 1540; Well F197, 960, 990, 1080, 1230, 1260, 1440, 1500, 1560-1620.

Remarks. This is very similar to the Loxoconcha gr ovulata Costa described from the lower Tortonian-Early Messinian of Capo S. Marce, western Sardinia by Bonaduce \& Russo (1984). Our specimens differ in having a less curved dorsal margin.

Family Schizocytheridae Howe, 1961

Genus Neomonoceratina Kingma, 1948

Neomonoceratina keiji Szczechura, 1989

(Pl.3, fig.13)

1989 Neomonoceratina keiji Szczechura p. 921-992, pl. 8, fig. 2$7 \& 10,11$.

Material.190 Carapaces and 20 valves from all wells and all depths; No A12606-611.

Diagnosis. A species of Neomonoceratina with reticulation present but poorly developed; reticulation is strongest to the posterior of dorsal sulcus and below the ventral ridge; much of the surface is smooth with prominent pore cones. Remark. This is similar to Neomonoceratina miocaenica (ElWaer 1988) from the Upper Miocene of N.W Libya. ElWaer's species differs in having stronger reticulation present over the whole surface, a less accentuated ventral ridge and the antero-dorsal ridge running from eye tubercle to join with the median ridge. The variation in the reticulation in figured species compared with $N$. miocaenica is suggestive of ecophenotypic variation. However, no variation has been observed in the specimens studied and as this common species is found throughout the wells, reticulation is regarded as a genuine character for differentiating species. This species occurs throughout the Marada Formation as well as in the Hommath formation of ?middle Miocene age of the western coast of the Gulf of Suez (Egypt).

\section{Neomonoceratina laskarevi Krstic \& Pietrzeniuk,1972} (Pl.3, fig. 12)

1972 Neomonoceratina laskarevi Krstic \& Pietrzeniuk, 110, pl.1-3. 1973 Neomonoceratina mouliana Sissingh, Doruk Stereo Atlas of Ostracod shells, 1,

1980 Neomonoceratina laskarevi Krstic \& Pietrzeniuk, Van Hinte ,212, pl. 1.2, fig. 5 .

1982 Neomonoceratina laskarevi Krstic \& Pietrzeniuk, Aruta, 118, pl.4, figs 15-17.

1985 Neomonoceratina mouliana Sissingh, El-Waer, 40, pl. 4, figs 36. 1988 Paijenborchellina laskarevi Krstic \& Pietrzeniuk, Bonaduce et al, pl. 1, fig. 5 .

1989 Neomonoceratina ruggierii Szczechura, 293-294, pl. 8, figs. 1, ?8,9,12-15.

Material. 34 carapaces and 4 valves from all wells and horizons; No A12602-05.

Remarks. The reticulation is not as prominent as that illustrated by other workers, while the pore conuli are more prominent. The specimens figured by Van Hinte (1980) and Bonaduce, et al. (1988) are very similar to the specimens studied here; it is not clear whether the differences noted warrant specific or subspecific separation. The figured specimen differs from typical $N$. laskarevi in having a more ornamentated posterodorsal area, and a more prominent median ridge.

\section{Family Trachyleberididae Sylvester-Bradley, 1948 \\ Genus Acanthocythereis Howe, 1963. \\ Acanthocythereis hystrix (Reuss, 1850)}

$$
\text { (P1.4, fig.8) }
$$

Material. Two adult carapaces and one Juvenile carapace from Well F1-97 at depth 1590 and 1800ft ; No A12633-635. Remarks. This species has a long stratigraphic range from Miocene to Recent, and is widely distributed in the Mediterranean area and adjoining regions. A complete synonymy can be seen in Athersuch (1979) and Mostafawi (1981). It was first described from the Badenian (Middle Miocene) of the Vienna Basin (Reuss 1850).

Genus Actinocythereis Puri, 1953

Actinocythereis libyaensis El-Waer, 1992

$$
\text { (Pl.4, fig. 5) }
$$

Material. 4 carapaces from Well Cla-97 at depth of 770 feet; No A12551-553.

Remarks. This was described from the Upper Miocene $\mathrm{Al}$ Khums Formation of North west Libya (Al-Waer, 1992).

\section{Actinocytheries spinosa El-Waer, 1988.}

(Pl.4, fig.7)

Material. One left valve from Well G1-97 at depth of 1040 feet; No A12550.

Remarks. El-Waer based his new species on 3 left valves from the Late Miocene Al khums Formation. These are all more elongate than the specimen described here, so there is the possibility of sexual dimorphisim, those figured by ElWaer being male while that described here is female. A feature not mentioned by El-Waer is the presence of reticulation at the posterior as well as anterior.

\section{Actinocythereis sirtensis sp. nov}

$$
\text { (Pl.4, figs 1-3 ) }
$$

Derivation of name. After the Sirt Basin

Diagnosis. A species of Actinocythereis characterized by well developed surface reticulation as well as three longitudinal rows of spines.

Holotype. Female carapace; No A12557, well F1-97 at depth of $1490 \mathrm{ft}$.

Material- five carapaces; No A12554-557 from Wells C1a97, 1730, $1850 \mathrm{ft} . \&$ F1- 97, 1590.

Description. Carapace subrectangular in lateral view; maximum height at anterior cardinal angle; dorsal margin straight; ventral margin slightly convex and curved upward posteriorly; anterior margin broadly rounded, with marginal denticles and a row of eight small tubercles around the anterior rim; posterior margin subtriangular, 
with spines. Carapace ornamented by three longitudinal rows of spines or nodes; dorsal row consists of six spines, some being bifid; median row starts from antero-central area and consists of six spines formed into two groups of three spines separated by a small gap; seven spines form the median row which ends in a central posterior position; ventral row is the shortest, consists of eight spines starting at the middle of the ventral margin runnings backwards ending in the postero-ventral area. The remainder of carapace reticulate with subrounded pits. Internal features not known. Sexual dimorphisim is distinct, males being more elongate.

Dimensions of figured specimens (in $\mu \mathrm{m}$ ). Length Height $\mathrm{L} / \mathrm{H}$

$\begin{array}{llll}\text { Male right carapace; No A12554 } & 700 & 365 & 1.91\end{array}$

$\begin{array}{llll}\text { Male left carapace; No A12555 } & 672 & 342 & 1.96\end{array}$

Male left carapace; No A12556 $\quad 638 \quad 341 \quad 1.87$

Female right carapace; No A12557 $658 \quad 332 \quad 1.98$

Remarks. This differs from Actinocythereis spinosa El-Waer, 1988 in having a well defined median row of spines, while $A$. spinosa lacks the well defined reticulation of $A$. sirtensis; A. libyaensis differs in the arrangement of the median large spines as well as having a smooth carapace.

\section{Genus Carinovalva Sissingh, 1973 \\ Carinovalva carinata (Moyes), 1965}

$$
\text { (Pl.1, fig.19) }
$$

Material. 30 carapaces and two valves distributed throughout all three wells; No A12597-601.

Remarks. This species was first described from the Upper Miocene of the Aquitain Basin and is also recorded from the Rhone Basin (Carbonnel, 1969), from the Upper Miocene Tortonian of Portugal (Nascimento, 1983) and from the Upper Miocene of Al Khums Formation of North West Libya (El-Waer, 1988).

Genus Chrysocythere Ruggieri, 1962

Remarks. Species of Chrysocythere are separated on the basis of lateral outline, the exact pattern of the median longitudinal ridge, and details of the intercostal ornamentation. Using these criteria three distinct species can be recognized in the material studied. The first of these is regarded as being conspecific with Chrysocythere cataphracta cataphracta Ruggieri, 1962 in which the median ridge ends before reaching the posterior, and the intercostal ornamentation is dominated by vertical connecting ribs giving rise to vertically oriented elongate reticulation. The second species is placed in C. paradisus Doruk,1973; the ornamentation is identical, although the posterior dorsal angle is less rounded than in Doruk's illustration. $C$. paradisus differs from $C$. cataphracta in having smaller, more even reticulation between the longitudinal ridges. $C$. cataphracta muricata El-Waer 1992 differs from C. paradisus in being slightly elongated and in details of ornamentation. The third species is identified as C. alkhumia El-Waer 1992 which is similar to $C$. cataphracta, but has a prominent downturned median ridge at the posterior giving a very characteristic outline to the median ridge. Chrysocythere cataphracta of Bassiouni (1979) differs from all these Libyan specimens in details of longitudinal ridges and intercostal ornamentation.

Variation in the intercostal ornament is seen in illustrations of $C$. cataphracta given by various authors. The longitudinal ridges are connected by a series of vertical ribs giving the impression of very coarse vertically orientated elongate reticulae; in Ruggieri's original illustration these elongate reticulae can be seen to be subdivided by weak horizontal reticulation; this character appears to vary in strength, i.e. in Aruta (1982), the intercostal ornamentation seems to consist of small even reticulation, while in Carbonnel (1986), the reticulation is almost non existent as in the Libyan specimens. The dorsal margin of the left valve is parallel to the ventral margin and does not show the slight posterior tapering seen in the illustration of Ruggieri (1962) and of Aruta (1982) but is similar to those of Sissingh (1972) and Carbonnel (1986).

Material. C.cataphracta cataphracta, 15 carapaces and 1 valve, Well C1a-97, 770,1160, 1340, 1400, 1730; Well G1-97, 640, 1130, 1350; Well F1-97, 990, 1020. 1170; C. paradisus, 8 carapaces and 1 valve, Well C1a-97, 770; Well F1-97, 600, 660,690, 900, 930, 1140, 1530; C.alkhumia, i valve, Well F1-97, 930 .

\section{Genus Cistacythereis Uliczny, 1969}

Cistacythereis qabilatashurfahensis El-Waer, 1992.

$$
\text { (P1.4, fig.12) }
$$

Material. Six carapaces from Wells C1a-97 at 770 and 1160 $\mathrm{ft}$ and F1-97 at 1260-1290 ft; No A12594-596.

Diagnosis. A species of Cistacythereis with three strong longitudinal ridges and a fourth ridge parallel to the anterior margin; prominent deep fossae and strong muri. Remarks. This was described from the Upper Miocene $\mathrm{Al}$ khums Formation, N.W. Libya.

\section{Cistacythereis cf. C. caelatura Uliczny,1969}

(Pl.4, fig.13)

1989 Cistacythereis of C. caelatura Szczechura, 298-99, pl.1, fig.2, pl.3, figs 10-12.

Material. 20 carapaces and six valves from Wells C1a-97 at $770,830,950,1070-1160$, and F1-97 at 720-810, 870-930, 9901050,1140, 1170. ; No A 12656-662.

Remarks. This is similar to $C$. caelatura originally described from the Pliocene of Greece (Uliczny,1969), but differs in having weaker lateral longitudinal ridges and more numerous intercostal reticulation. The specimens described by Szczechura \& Abd-Elshafy (1989) from the ?Miocene Hommath Formation of Egypt and the Marada Formation of Libya show variation in ornamentation but include specimens identical to those described here.

Genus Falsocythere Ruggieri, 1972

Falsocythere maccagnoi Ciampo, 1971

(Pl.3, figs 18, 21)

1971 ?Occultocythereis maccagnoi Ciampo, p.27, pl.2, fig.7-9, 
pl. 3,fig.1.

Material. Four carapaces from Wells C1a-97 at depth of 1730 feet and F1-97 at depth of $1590 \mathrm{ft}$; No A12684-686.

Remarks. This is similar to the specimen from the Upper Miocene (Messinian), of the Borehole B1-NC35A, situated in north east Tripoli figured by Van Hinte (1980) as Occultocythereis dhorni Puri; it differs in the dorsal ridge which is strongly curved rather than straight as shown in Van Hinte's figure, as well as in the surface ornamentation. Van Hinte's material differs from Occultocythereis dhorni as described and figured from the Mediterranean area by Puri (1968, pl.1 fig. 8), in having a straight ventral margin instead of a convex margin and lacks the prominent swelling in the antero-central area. Falsocythere maccagnoi has been described from the Pliocene of Algeria (Yassini 1979) the Marada Formation of the central Sirt Basin, and the Hommath Formation Egypt (Szczechura \& Abd-Elshafy 1989).

\section{Neocaudites nudicosta (Yassini 1979)}

(Pl.2, fig. 18)

Material. 1 carapace; No A12687, from Well F1-97, $1590 \mathrm{ft}$. Remarks. Our specimen is similar to that illustrated by Bonaduce et al (1992)from the Upper Miocene of offshore Tunisia; these authors also placed Szczechura \& AbdElshafy's Falsocythere maccagnoni in this species.

\section{Genus Hermanites Puri, 1955 \\ Hermanites haidingeri haidingeriReuss, 1850}

(Pl.4, fig. 6)

Material. Six carapaces from Well F1-97 at depth 1020ft; No A12703-705.

Remarks. This was first described from the Upper Miocene of the Vienna Basin (Reuss, 1850). The specimens studied here differ from Hermanites haidingeri described from the Pliocene of Algeria (Yassini, 1979-80) in having a slightly shorter dorsal ridge. This species is commonly placed in the genera Cletocythereis Swain 1963 or Grinioneis Liebau 1975.

\section{Hermanites zaltanensis sp. nov.}

(Pl.2, fig.13; Pl.4, figs 4,9,11)

Derivation of name. After Jabal Zaltan, $60 \mathrm{~km}$ south of the Marada Oasis.

Diagnosis. A species of Hermanites with three longitudinal ridges; dorsal and median ridges curved and nearly parallel; dorsal ridge separated from eye tubercle by depression, joining the median ridge posteriorly; ventral ridge straight, surface ornamented by coarse reticulation. Holotype. Male right carpaces; No A12698, well C1a-97 at depth of $770 \mathrm{ft}$.

Material. Five carapaces; No A12698-702; Well C1a-97, 770 $\mathrm{ft}$ and F1-97, 660 .

Description. Carapace elongate to subrectangular in lateral outline; the maximum height at anterior cardinal angle; dorsal margin appears to be humped at posterior due to the overhanging of the dorsal ridge; ventral margin straight to slightly concave in the middle; anterior margin broadly rounded; posterior margin concave in the upper part, while the ventral part possesses five short spines; three longitudinal ridges are present; the dorsal ridge is curved, ending in a slight node which connects the dorsal and median ridges; a weak median ridge runs from the subcentral tubercle towards the posterior and is nearly parallel to the dorsal ridge; the ventral ridge is strongly developed and almostly straight, starting from anteroventral area and running backwards nearly parallel to the ventral margin, ending in a small node in the posteroventral area. The surface of the carapace is reticulate, with deep fossae of different polygonal shapes. Rounded subcentral tubercle is prominent. The eye tubercle is very clear and rounded. Internal features could not be observed. Sexual dimorphisim clear and distinct, with more elongate males

Dimensions of figured specimens (in $\mu \mathrm{m}$ ). Length Height $\mathrm{L} / \mathrm{H}$

Male right carapace; No A12698 $952 \quad 467 \quad 2.03$

Female right carapace; No A12699 $841 \quad 483 \quad 1.74$

Female left carapace; No A12700 $875 \quad 475 \quad 1.84$

Remarks. This is very similar to $H$. abundans El-Waer1992 described from the Upper Miocene Al Khums Formation of North west Libya. $H$. zaltanesis differs from the latter in having a broadly rounded anterior margin unlike the obliquely rounded margin of $H$. abundans, in having a stronger ventral ridge, and in details of the reticulation. It is also larger (male 952 cf. 826). Hermanites transcostata Khalaf, 1982 from the middle Miocene of Iraq differs in the outline of the ventral and anterior margins, and in having much coarser surface reticulation. $H$. zaltanensis is very similar in lateral outline to $H$. tschopi (Van Den Bold, 1946) described from the Neogene of Senegal and Guinea (Carbonnel, 1985), but the latter differs in being shorter than our specimens, and the ventral ridge connects with the anterior ridge. There is doubt about the generic assignment; we have followed El Waer 1992.

\section{Genus Keijella Ruggieri,1957.}

Keijella africana El-Waer, 1988

(Pl.1, fig.21)

Material Ten carapaces and one valve from wells C1a-97 at 770 and $1130 \mathrm{ft}$ and F1-97 at $750 \mathrm{ft}$; No A12612-14.

Remarks. Keijella africana was described from the Upper Miocene $\mathrm{Al}$ khums Formation and the ?middle Miocene of Libya and Egypt (Szczechura \& Abd- Elshafy 1989).

\section{Keijella punctigibba Capeder,1902} (Pl.1 fig.20)

1902 Cythere punctigibba Capeder, pl. 14, figs. 26 1987 Keijella punctigibba Capeder, Keen, pl.2, fig.4.

Material. 14 carapaces and two valves from Wells Cla-97 at depth 770 \& $950 \mathrm{ft}$ and G1-97 at $750 \mathrm{ft}$; No A12615-618.

Description. Carapace ovate to subrectangular in lateral view, with very distinct postero-ventral spine. Ornamentation consists of a series of slots arranged into 7-8 rows mainly located in the central-posterocentral area; 
ventral slots run from the antero-ventral area backwards into the postero-ventral area, and anterior slots are G.E. $280 \mathrm{ft}$ present in the central anterior area; remainder of carapace is smooth. Some specimens bear spines along the anterior and posterior margins. Sexual dimorphism is pronounced, males being more elongate than females. Remarks. This species was first described from the Tortonian of Scrivia, Italy (Capeder 1902) and is also recorded from the Upper Miocene of Malta (Keen 1987). It is very similar to Keijella hodgii Bradley, but differs in having larger areas of ornamentaion, and also in lateral outline.

\section{Family Xestoleberididae Sars, 1928 Genus Xestoleberis Sars, 1866 Xestoleberis cf. reymenti Ruggieri, 1967 (Pl.4, fig.16)}

Materia. 30 carapaces from throughout all wells at all horizons; No A12694-697.

Remarks. This differs from Xestoleberis reymenti described from the Miocene of Alloctono Dell val Marecchia of Italy in having a slightly concave ventral margin.

\section{Family uncertain}

Genus Ruggieria Keij, 1957.

Ruggieria tetraptera tetraptera Sequenza, 1869

(Pl.4, fig.14)

Material. 41 carapaces and two valves from all wells and horizons; No A12636-640.

Remarks. The figured specimen is close to Ruggieria tetraptera tetraptera figured by Keen (1987) from the upper MIocene of Malta, and to the specimen figured by Fig. 3. The proposed biozones of the Marada Formation showing correlation El-Waer (1992) from the Upper Miocene Al Khums between the wells. The datum is taken as the top of the Burdigalian. A, Formation. Szczechura \& Abd-Elshafy (1989) described Pokornyella deformis minor Biozone, B Aurila soummamensis Biozone, C this species from ?middle Miocene Marada Formation of Interval Biozone, D, Ruggieria tetraptera tetraptera Biozone.

the central Sirt Basin and the western coast of the Gulf of Suez, Egypt.

\section{Ruggieria aff dorukae Bassiouni, 1979}

$$
\text { (Pl.4, fig.10) }
$$

Material. Two carapaces and one valve from Well G1-97 at depth $1260 \mathrm{ft}$; No A12641-643

Remarks. Ruggieria dorukae was recorded from Lower Miocene of Turkey (Bassiouni,1979) and subsequently recorded from the Burdigalian of south west Anatolia, Turkey (Gokçen,1986). The Libyan specimens differ from these in the presence of a smooth area in the anterior region; this feature is original, but preservation in two of the specimens makes it difficult to describe. It is not clear whether this is of specific importance or not, and lack of material makes it impossible to discern whether or not variation exists within the Libyan material.

Mostafawi(1987) figured specimens of Ruggieria dorukae from the Middle Miocene of Kos, Greece, which also have a smooth area at the anterior, although this area is smaller than in the Libyan specimens.

OSTRACOD FAUNAS FROM THE MARADA FORMATION
The ostracod fauna described here differs from previously described Miocene faunas from Libya (Bellini 1969; Van Hinte et al 1980; Innocenti and Pertusati 1984; El-Waer 1988, 1992) due to differences in age and facies. It also differs from the fauna described by Szczechura \& Abd-Elshafy (1989) from the Miocene of Egypt and the Marada Formation of the north central Sirt Basin. It is difficult to account for this latter difference; the presence of Pokornyella deformis minor and Aurila of soummamensis in their samples suggests an Aquitanian age, i. e Lower Miocene. If this is correct, this could be a factor in accounting for the differences, i.e their fauna is of Aquitanian age while the majority of the species recorded here come from Burdigalian or later sediments. Slight differences in facies and geographical location may also be involved. Fifty five species have been identified in this study; twenty two of which have been described from various localities in the Mediterranean area and north Africa; six species are new; the remainder are left in open nomenclature, although some of these are very similar to species already described. Sixteen species are important for stratigraphical age 


\begin{tabular}{|c|c|}
\hline STAGES & TURKEY \\
\hline & Gokcen 1985 \\
\hline \multicolumn{2}{|l|}{ Tortonian } \\
\hline Serravallian & \multirow{2}{*}{ 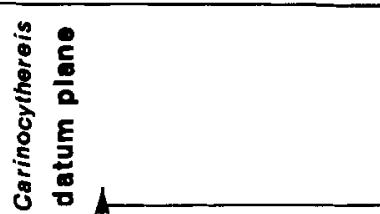 } \\
\hline Langhian & \\
\hline Burdigalian & $\begin{array}{c}\text { Neomonoceratina helvetica } \\
\text { Aurila soummamensis } \\
\text { Super zone }\end{array}$ \\
\hline Aquitainian & \\
\hline
\end{tabular}

determination; four of these are restricted to the Lower Miocene, nine to the Upper Miocene, while three species have longer ranges but still provide stratigraphical information. In general the species recorded in Fig. 3 are part of a widespread Mediterranean fauna, and most of the remaining species are closely related to widespread species. The fauna is markedly different from that described from Iraq (Khalaf,1982) where there are no species found in common to the two countries. The Libyan fauna also differs from those of central and northern Europe.

The stratigraphical range of the ostracods is based on published records from localities in Algeria, Austria, Belgium, Cyprus, Egypt, France, Greece, Italy, Libya, Malta, Tunisia, and Turkey. The stratigraphical and geographical distribution of each species has been discussed in the systematic section.

Lower Miocene species. The typical species is Aurila soummamensis, described from the Burdigalian of Algeria, and from the lower Miocene of Turkey (Bassiouni, 1979). Gokçen (1984) used this species to define the Lower Miocene (Burdigalian) Biozone in the Neogene sequences of Turkey. Pokornyella deformis minor (Moyes 1965), described from the lower Miocene of Aquitain, France, and the lower Miocene of Turkey (Bassiouni, 1979 and Gokçen 1984) is also a useful marker species, restricted to the Aquitanian. Middle Miocene. No species have been found in this study which are restricted to the Middle Miocene; three species are present which are recorded from the Middle Miocene, but range into later periods: Cnestocythere truncata, (Aquitanian- Tortonian), Chrysocythere paradisus (LanghainTortonian), and Acanthocythereis hystrix (Langhain-Pliocene). Thus, although they are not restricted to the Middle Miocene, their first appearance indicates Middle Miocene or later periods, and the interval between their first appearance and first appearance of typical Upper Miocene ostracods can be regarded as Middle Miocene.

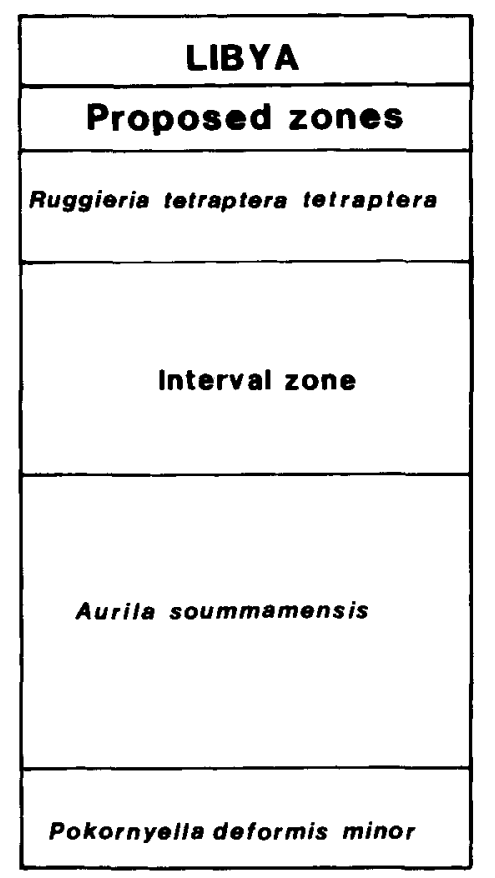

Fig. 4. Correlation between proposed biozonation of the Miocene of Turkey and Libya,

Upper Miocene species. Most of the species identified in this study are restricted to the Tortonian (Upper Miocene), e.g. Actinocythereis spinosa, A. libyaensis, Chrysocythere alkhumia, C. cataphracta, C. paradisus, Keijella punctigibba, Carinovalva carinata, while some species range into the Pliocene e.g. Acanthocythereis hystrix, Neomonoceratina laskarevi, Ruggieria tetraptera tetraptera.

\section{OSTRACOD BIOZONES OF THE MARADA FORMATION}

Ostracod biozones are proposed for the Marada formation in the eastern Sirt Basin based on the first appearance downhole of one or more index species. The species chosen are known to have a wide geographical distribution, their stratigraphic ranges are short and well documented, they are easily identified, and they are reasonably abundant.

Several biozonations based on ostracods have been published for different provinces of the Mediterranean Neogene: Carbonnel (1969) on the Aquitanian-Tortonian of the Rhone basin in France, Sissingh (1972) on the late Cenozoic of the south Aegean Islands, and Jircek (1974), on the Neogene sediments of the Czechoslovakia and Paratethys. Gokçen (1984) recognised a Burdigalian-early Langhian zone based on Neomonoceratina helvetica (Oertli) and Aurila soummamensis in the Neogene sequences of Turkey (Fig.4). The following four biozones have been recognised in the Marada Formation of the sequences studied, in ascending order (Fig. 3.).

A-Pokornyella deformis minor Biozone. The top of this zone is recognised by the first occurrence downhole of Pokornyella deformis minor; its base has not been determined. This zone is probably equivalent to the Aquitanian.

B-Aurila soummamensis Biozone. The top of this zone is recognised by the first occurrence downhole of Aurila soummamensis; the base is defined by the first appearance downhole of Pokornyella deformis minor. This is equivalent to the Burdigalian.

C- An interval Biozone. This zone lies between the top of 
the Aurila soummamensis zone and the level taken to be the base of the Ruggieria tetraptera tetraptera Zone. This is taken to be equivalent to the Middle Miocene but as discussed earlier there is a lack of characteristic species.

D-Ruggieria tetraptera tetraptera Biozone. This assemblage zone is recognised by the abundance of characteristic Upper Miocene species.

\section{Manuscript received June 1992 \\ Manuscript accepted October 1992}

\section{REFERENCES}

Arambourg, C., \& Magnier, P., 1961. Gisements de Vertébrés dans le bassin Tertiaire de Syrte (Libye). C. R. Séanc. Acad. Sci.Fr. , 252, No. 8, 1181-1183

Aruta, L., 1982. Gli Ostracodi del saheliano (Miocene mediosuperiore) di c. Pestavecchia (Bonfornello, Palermo),.Boll. Soc. paleont. Ital., 21, 113-132.

Aruta. 1., and Ruggieri. G., 1980. Nuovo Ostracode marino del Saheliano dell Italia meridionale. Boll. Soc . paleont. Ital., 19, 21-24.

Ascoli. P., 1967. Preliminary report on the Ostracoda of the type Tortonian. Giorn. Geol., ser. 2a, 35 (2), 31-54.

Athersush, J., 1979. On Acanthocythereis hystrix (Reuss). Stereo-Atlas of Ostracoda Shells., 6, 133-140.

Bhatia, S. B., \& Mandwal, N. K., 1960. Burdigalian Ostracoda from the Surat-Broach area, Western India. Jour. Pal.,34, 280-284.

Banerjee. S., 1980. The stratigraphic Lexicon of Libya. Industrial Research Centre,Tripoli No.13, 300p., Tripoli.

Barr, F.T. \& Weegar, A. A., 1972. Stratigraphic nomenclature of the Sirte Basin, Libya. Petrol. Explor. Soc. Libya, 129p.

Bassiouni, M. A., 1962, Ostracoden aus dem Mittelmiozan in N. W Deutschland. Roemeriana., 3, 123p.

Bassiouni, M. A., 1979. Brackish und marine Ostracoden (Cytherideinae, Hemicytherinae, Trachyleberidinae), aus dem Oligozän und Neogen der Türkei., Geo. Jb., 31, 3-195.

Bellini, E., 1969. Biostratigraphy of the "Al Jaghbub (Giarabub) Formation" in eastern Cyrenaica (Libya). Proc. 3rd African. Micropal. Colloquium., 165-183.

Benfield, C. A., \& Wright, P. E., 1980. Post Eocene sedimentation in the eastern Sirt Basin Libya, Second. Symp. on Geol. of Libya., 463499.

Bishop,W.W., Miller, J. A., \& Fitch, F. J., 1969. New Potasuim-Argon age determinations relevant to the Miocene fossil Mammal sequences in East Africa. Am. J. Sci., 267, 669-699.

Bonaduce, G., and Pugliese, N. 1975. Ostracoda from Libya, Pubbl. Staz. Zool. Napoli. 39,129-135.

Bonaduce, G., and Russo, A. 1985 The Miocene Ostracodes of Sardinia, Boll. Soc. Palaeont. Italy, 23. 421-437.

Bonaduce, G., Ruggieri, G., Russo, A., \& Bismuth, H. 1992. Late Miocene Ostracods from the Ashtart 1 well (Gulf of Gabes, Tunisia). Boll. Soc. Palaeont. Ital., 31, 3-93.

Bonaduce, G., Bismuth, H., Ruggieri, G., Russo, A., \& Mascelaro, P. 1988. Marine Ostracods of the Upper Miocene of Well Ashtart1 (Gulf of Gabês, South eastern Tunisia)., In: Hanai, T., Ikeya, N., \& Ishizaki, K. (Eds.), Evoulutionary Biology on Ostracoda, Proc. Ninth. Inter. Sypm. on Ostracoda., Elsevier, 1087-1100.

Bordovsky, H. R., 1965. Accumulation and transformation of organic substance in marine sediments. part I-IV. Marine Geol. 3 (1-2), 3-114.

Breman, E., 1975. Distribution of Ostracodes in the bottom sediments of the Adriatic Sea. Dissert. Vrije Univ. Amsterdam, Off set Krips Repr., Meppel, 165p.

Carbonnel, G., 1969. Les ostracodes du Miocène Rhodanien.
Systématique, biostratigraphie, écologique, paléobiologie Docum. Lab. Geol. Fac. Sci. Lyon., 32, 469p.

Carbonnel, G., and Magne', J. 1977. Microfaunes (Ostracodes et Foraminiferes) du Pliocene de $\mathrm{L}^{\prime}$ Ampurdan (Espagne), Rev. Espan.Micropaleont., 9, 347-359.

Carbonnel, G., 1986. Ostracoedes Tertiares (Paléogène and Néogène), du Basin Sénégalo- Guinéen. Doc. Bur. Rech. Géol Min., Orléan, 101. 34-231.

Coutelle. A., and Yassini. I., 1974. Ostracodes du Miocene dela vallee dela Soummam, Algérie nord-orientale. Rev. Esp. Micropal. 6, 85-99.

Desio, A., 1935. Studi geologici sulla Cyrenaica sul Deserto Libico sulla Tripolitania e sul Fezzan Orientali. Missione Scient. R. Acc d'Italia a Cuffra (1931). 1. Roma.

Desio, A., 1928. Risultati Scientifici della Missione alla Oasi di Giarabub. Fasc. I. La morfologia. R. Soc. Geol. Ital., 1-82.

Desio, A., 1971. outline and problems of the geomorphological evolution of the Libya from the Tertiary to the present day. Symp. Geol. Fa. Sc. Univ. Tripoli. Libya., 11-36.

Dieci. G., et Russo. A., 1964. Ostracodi Tortoniani dell, Appennino Settentrionale. Boll. Soc. Paleont. Ital., 3, No1, 33- 88.

Doruk, N., 1973. On Chrysocythre pardisus Doruk sp. nov. StereoAtlas of Ostracod Shells, 1. 2: 89-92.

Doruk, N., 1979. Neogene and Quaternary Ostracoda of Adana and Antalya Basin (Turkey). Proc. 7. Internat. Sympos. Ostracodes., 165172, Beograd.

Eames, F. E., Banner,F.T., and Blow W.H., 1962. Fundamentals of midTertiary Stratigraphical Correlation, Cambridge University Press, 163p.

Edwards, R., 1944. Ostracoda from Duplin marl (upper Miocene), north of Carolina. Journal Paleont., 18, 505-528.

El-Hawat, S. A., 1980. Carbonate-Terrigenous cyclic sedimentation and Palaeogeography of the Marada Formation (Middle Miocene), Sirt Basin, Libya. Second. Symp. Geol Libya., 427-447.

El-Waer A., 1988. Late Miocene Ostracoda from NW Libya.J. micropalaeont., 7, 45-52.

El-Waer, A., 1992. Miocene Ostracodda from Al Khums Formation, Northwestern Libya. In: Salem, M.J., Hammuda, O.S., \& Eliagoubi, B.A. (Eds.), The Geology of Libya, 4, Elsevier, 1457-1481.

Fichtel , L., and Moll, J. P. C. V., 1978. Mikroschopische und naute Schiffen, nach der Natur gezeichnet und beschreiben. Camesina, 124p., Wien.

Gokçen, N.,1986. The Burdigalian Ostracodes from the area of S.W. Anatolia (Turkey). Revue de Micropaléont., 28, 41-57.

Gokçen, N., 1984. Neomonoceratina helvetica Superzone and Carinocythereis Datumplane in Neogene sequences of Turkey, Newsl. Stratigr., 13 (2), 94-103.

Guha, D. K.,1961. A note on the Ostracoda from lower Miocene of the Chaasra, Kutch. Bull. Geo. Min. Met. Soc. India., No 24.

Hughes, M. J., 1974. Foraminifera from Borehole J(C1-95) Sirte Basin, Libya. Palaeont. Dept. Inst. Geol ., London. Unpublished Rep. No. PDL 74/45.

Innocenti, F \& Pertusati, P., 1984. Geological map of Libya, 1; 250,000. Sheet Al AQAYLAH (NH34-5), Explanatory Booklet. Industrial Research Centre.Tripoli. Libya., 105p.

Jiricek, R., 1974. La correlation du Néogène supérieurdes regions de la Paratéthys et de la Téthys. Géol. Sborn., Géol. Carpathica 25, 145160., Bratislava.

Keen, M. C., 1982. Intraspecific variation in Tertiary ostracods. In : Bate, R. H., Robinson, E., \& Sheppard,L.M. (Eds.), Fossil and Recent Ostracods. Ellis Horwood Ltd., Chichester, 381-405.

Keen M. C., 1987, Microfossils from Gozo, Proc. Geol. Soc. Glasgow, 24-29.

Keij, A. J., 1979. Brief review of type species of Genera from the KIngma collection, Proc. 7. internat. symp. on Ostracodes., Beograd. 
59-63.

Keij, A.J., 1957. Eocene and Oligocene Ostracoda of Belgium. Inst Sc. R. Nat. Belg., Mem,136, 210, pl. 23, Bruxelles.

Keij, A. J., Kaasschieter, J. P.H., \& Drooger, W. C.,1955. The microfauna of the Aquitanian-Burdigalian of south west France. Verh. Kon. Ned. Akad. Wetensch. Afd. Natuuk., 1, 101-136.

Khalaf, S. K., 1982. On Hermanites transversicostata. Stereo-Atlas of Ostracod Shells, 9, 59-62.

Khosla, S., 1978. Lower Miocene ostracoda from Jamnagar and Porpander districts, Gujarat, India. Micropaleontology., 24, 251296.

Khosla, S. C., \& Pant, P. C., 1981. Ostracod genus Actinocythereis from the Eocene and Oligocene beds of Kutch. Proc. IX Indian Coll. Strat. 156-166.

Kollmann, K.,1960. Cytherideinae und Schulerideinae n. subfam. (Ostracoda) aus dem Neogen des Ostlichen Oesterreich. Mitt Geol. Ges. Wien., 51, 89-195.

Krstic, N. \& Pietrzeniuk, E.,1972. Paijenborchellla (Eopaijenborchella) laskarevi, eine neue Ostracoden art aus dem Oberen Torton des Pannonischen Beckens. Geologe., 21, 100-109.

Mostafawi, N., 1981. Marine Ostracoden aus dem Oberpliozän im Mittelteil der Insel Kos (Griechenland)., Meyniana. 33, 133-188.

Mostafawi, N., 1987. Miozäne Ostracoden von West-Kos, Griechenland, Senckenbergiana lethaea, 68, 225-247.

Mostafawi. N., 1989. Limnische und marine Ostracoden aus dem Neogen der insel Rhodos (Griechland), Cour. Forsch. Inst. Senckenberg,113, 117-157

Moyes, J.,1965. Les Ostracodes du Miocène Aquitanian. Essai de paléoécologie stratigraphique et de palégéographie. Drouillard. édit., Bordeaux., 339p.

Muller, G. W., 1894. Die Ostracoden des Golfes von Neapol und der angrenzanden Meeres-abschnittei Naples sta . Zool. Fauna Flora Golfes, Neapel Monagr. 21, 403.

Nascimento, A., 1983. The Ostracoda fauna of the Portuguese Neogene and its relationship to those from the Atlantic and Mediterranean Basin. In Maddocks, R.F. (Ed.), Application of Ostracoda Univ. Houston Geosc., 429-436.

Neale, J. W., 1983. The ostracoda and Unifomitarianism.1. The later record: Recent, Pleistocene and Tertiary, Proc. Yorks. Geol Soc., 44, 305-326.

Oertli, H. J., 1956. Ostracoden aus der Oligozänen und Miozänen Molasse der Schwiez. Schwiez. Palaont., 74, 189.

Oertli, H. J., 1961. Ostracodes du Langhien-Type. Riv. Ital. Paleont. Strat., 67, 17-44.

Reiss, Z., and Gvirtzman, G., 1966. Borelis from Palestine Eclog. Geol. Helv. 59, 437-448.

Ruggieri, G.,1958. Alcuni Ostracodi del Neogene Italiano. atti. Soc. Ital. Nat ., 97, 127-146.

Ruggieri, G., 1962. Gli Ostracodi marini del Tortoniano (Miocene medio-Superiore)di enna nella Sicilia Centrale, Paleont. Ital. 56, Mem. 2, 1-68.

Ruggieri, G., 1967. Due Ostracofaune dell Miocene Alloctono della val Marecchia (Appennino Settentrionale). Riv. Ital. Paleont., 351-384.

Ruggeri, G., Russo, A., \& Bassio, A., 1977. Pokornyella Italica (Ostracoda, Podocopida), Nuova species del Miocene Superior Mediterraneo. Boll. Soc. Paleont. Ital.,16, 129-136.

Russo, A.,1964, Ostracoda Langhiani del Pescale (Appennino settentrionale modenese). Boll. Soc. Paleont. Ital., 3, 227-251.
Said, R., 1962. The Geology of Egypt. Elsevier, Amsterdam. 368p.

Savage, R. J. G., \& Hamilton, W. R., 1973. Introduction to the Miocene mammal fauna of Jabal Zelten, Libya. Bull. Br. Mus. ( Nat. Hist ), Geol., 22, 515-527.

Savage, R., and White, M., 1965. Two Mammal faunas from the early Tertiary of central Libya, Proc. Geol. Soc. London.,1623, 89-91.

Selley, C.R., 1969. Nearshore marine and continental sediments of the Sirt Basin Libya, Quart. Jour. Geol.Soc. London., 124, 419-460.

Sequenza, G., 1879. Le Formazioni terziarie nella provincia di Reggio (Calabria) Mem. Cl. Sci. Fis. Mat. Nat. R. Acc., Lincei, Ser. 3. 6, 416 .

Sissingh, W., 1972. Late Cenozoic Ostracod of the south Aegean Island Arc. Utrecht. Micropaleont. Bull., 6, 1-187.

Sissingh, W., 1972. Ostracodes from the Sahelian near Carnot, North Algeria., Proc. Kon. Nedel. Akad. Weten., ser. B, 75, 85-95, Amsterdam.

Sissingh, W.,1974 .The Miocene Ostracoda from the HipparionBearing beds of Kastellios hill, centrale Crete. Koninkl. Nederl. Akademie Van Wetenschappen- Amsterdam., ser B, 77, 119-128.

Sissingh, W., 1976. Tentative Middle Miocene to Holocene Ostracode Biostratigraphy of the Central and Eastern Mediterranean Basin. Kon. Neder. Akad. van Wetenschappen, Amsterdam., Series. B, 79.

Stancheva, M.,1962. Ostracoda from the Neogene in north western Bulgaria, Tortonian. Trav Geo.l1, BWG, Ser, Paleont., 4, 4-75.

Sylvester-Bradley, P. C., \& Siveter, D. J., 1973. On Paijenborchella (Eopaijenborchella) mouliana, (Sissingh). Stereo-Atlas of Ostracoda Shells 1, 165-168.

Sylvester-Bradley, P. C., \& Ruggieri, G., 1973. On Chrysocythere cataphracta Ruggieri, Stereo-Atlas of Ostracod Shells 1, 31-34

Szczechura, J., 1980. Paijenborchellina libyca sp. n. from the upper Miocene of Libya. Acta Palentologica Polonica., 25, 225-232.

Szczechura, J., 1987. A new ostracode species, Neomonoceratina chromento- vensis sp. n., from Korytnica Basin (Middle Miocene; Holy Cross Mountains, central Poland), Acta. Geologica. Polonica., 37, 105-111.

Szczechura, J., \& Abd-Elshafy., 1989. Ostracodes and Foraminifera from the ?Middle Miocene of the western coast of the gulf of Suez, Egypt. Acta Palaeontologica polonica., 33, 273-342.

Uliczny, F.,1969. Hemicytheridae und Trachyleberididae (Ostracoda) aus dem Pliozän der Insel Kephallinia (Westgriechenland). Inaugural Dissertation. Munchent., 152p .

Van Den Bold, W.A., 1957. Oligo-Miocene Ostracoda from southern Trinidad, Micropaleontology., 3, 231-254.

Van Den Bold, W. A., 1963.Upper Miocene and Pliocene Ostracoda of Trinidad. Micropaleontology . 9, 336-424.

Van Den Bold, W. A., 1966. Les Ostracodes du Néogène du Gabon. Rev. Inst. Français du Pétr. 21, 155-189,

Van Hinte, J., Colin, J., \& Lehmann, R., 1978. Micropalaeontologic record of the Messian event at Esso Libya Inc. Well B-NC35A on Pelagian Platform, Second Symposuim on Geology of Libya., 205-244.

Yassini, I., 1979. Répartition des Ostracodes dans une série marine régressive $\mathrm{D}^{\prime}$ age Pliocéne dans la région $\mathrm{D}^{\prime}$ Alger, Algérie. Rev. Micropaléontologie, 22 , 89-124. 